\title{
Drugs that increase the risk of community- acquired pneumonia: a narrative review
}

\section{Adamantia Liapikou, Catia Cilloniz \& Antoni Torres}

To cite this article: Adamantia Liapikou, Catia Cilloniz \& Antoni Torres (2018): Drugs that increase the risk of community-acquired pneumonia: a narrative review, Expert Opinion on Drug Safety, DOI: 10.1080/14740338.2018.1519545

To link to this article: https://doi.org/10.1080/14740338.2018.1519545

Accepted author version posted online: 10 Sep 2018.

Submit your article to this journal $\pi$

View Crossmark data $\nearrow$ 
Publisher: Taylor \& Francis

Journal: Expert Opinion on Drug Safety

DOI: $10.1080 / 14740338.2018 .1519545$

\section{Article type: review}

Drugs that increase the risk of community-acquired pneumonia: a narrative review Adamantia Liapikou ${ }^{1}$, Cilloniz Catia ${ }^{2}$, Antoni Torres ${ }^{2}$

${ }^{1} 6$ th Respiratory Department, Sotiria Chest Diseases Hospital, Athens, Greece

${ }^{2}$ Department of Pneumology, Institut Clinic del Tórax, Hospital Clinic of Barcelona - Institut d'Investigacions Biomèdiques August Pi i Sunyer (IDIBAPS), University of Barcelona (UB) - SGR 911 - Ciber de Enfermedades Respiratorias (Ciberes), Barcelona, Spain

\section{Corresponding author}

Adamantia Liapikou

16th Respiratory Department, Sotiria Chest Diseases Hospital, Athens, Greece Email: mliapikou@yahoo.com

\section{Abstract}

Introduction: Community-acquired pneumonia (CAP), a major cause of morbidity and mortality, is the leading infectious cause of death in the developed world. Population-based studies and systematic reviews have identified a large number of risk factors for the development of pneumonia in adults. In addition to age, lifestyle habits, and comorbidities, some forms of pharmacotherapy may also increase the risk for CAP.

Areas covered: MEDLINE, CENTRAL, and Web of Science were used in 2017 to search for case-control, cohort studies, as well as randomized controlled trials and meta-analysis that involved outpatient proton pump inhibitors (PPIs), inhaled corticosteroids (ICSs), antipsychotics, oral antidiabetics, and CAP diagnosis in patients aged $>18$ years.

Expert opinion: Our review confirmed that the use of ICSs, PPIs or antipsychotic drugs was independently associated with an increased risk for CAP. We also identified a positive association between specific oral antidiabetics and the development of pneumonia.

Keywords: community-acquired pneumonia, risk factors, antipsychotics, inhaled corticosteroids, proton pump inhibitors

\section{Article highlights}

1. Several studies and randomized controlled trials reveal that some forms of pharmacotherapy, such as inhaled corticosteroids, proton pump inhibitors, and antipsychotic drugs, may increase the risk for CAP.

2. Data from RCTs and observational studies show increased rates of pneumonia in COPD patients treated with ICS, especially in those receiving higher doses, although this risk is not associated with higher mortality.

3. Proton pump inhibitors increase the risk for CAP, with the risk being highest at the beginning of therapy.

4. There is an association between antipsychotic drug use in elderly patients and pneumonia. The risk for pneumonia varies for the different classes of antipsychotics, being higher for atypical antipsychotics.

5. There is an obvious need for prospective trials to define the dose-dependent risk for pneumonia associated with each of these types of drugs and whether there are differences between different populations of patients. 
1. Introduction

Pneumonia frequently results in hospital admission and is a risk factor for prolonged hospital stays, placing a considerable financial burden on healthcare services (1). Reported annual incidences, which range from 1.6 to 16 cases per 1,000, vary between countries, probably due to differences in diagnostics, reporting, and socioeconomic factors (2). Prevalence and mortality are higher in elderly patients and will therefore further increase in the aging population of developed countries. The mortality rate varies between 0.1 and 0.7 cases per 1,000 each year. Community-acquired pneumonia (CAP) also has long-term implications for subsequent mortality. In a study from the Netherlands, the 1-, 5-, and 7-year mortality rates in patients who had recovered from CAP were reported to be significantly higher at $17 \%$, $43 \%$, and $53 \%$, respectively, than those in age- and sex-matched population controls $(4 \%, 19 \%$, and $24 \%$, respectively) (3). Targeted interventions to reduce the risk of developing CAP, based on understanding and recognizing the risk factors for CAP, are of primary importance in decreasing CAP-related mortality (4).

Studies from high-income countries have identified several risk factors for CAP including age, smoking $(5,6)$, earlier cases of pneumonia, environmental exposure to different substances, immunosuppression, comorbidities such as asthma and chronic obstructive pulmonary disease (COPD) $(7,8)$, as well as recent viral upper respiratory tract infections (URTI) (9). In addition, low body mass index (BMI), contact with children, and poor dental hygiene have also been identified as risk factors for CAP in a systematic literature review and meta-analysis of studies undertaken in Europe (5). Recently, it has been shown that medications administered to patients for underlying diseases (e.g., COPD, asthma, cardiac failure, ulcer, hypertension, dementia, and Alzheimer's disease) may also influence the development of pneumonia and its course $(4,10,11,12,13)$. Collectively, the current literature is inconclusive; the majority of randomized clinical trials (RCTs) were not designed with pneumonia as a prespecified or adjudicated endpoint, observational studies were not population-based and had a relatively short follow-up time and different statistical methods. Therefore, they not always report conclusive and concordant results.

Because of this heterogeneity, there is a need to update all the evidence to reach a more definitive conclusion for the studied drugs. We will critically review the evidence from RCTs, observational studies, reviews and meta-analyses linking pharmacotherapeutic agents and risk of pneumonia.

\section{Methods}

A search was conducted in Medline to identify studies exploring the association between risk of pneumonia and medication use. All studies had to be in English language and had to concern drug use as an intervention in persons $>18$ years old and for any indication, provided that the outcome was pneumonia.

The PubMed database was searched using the following search string: pneumonia AND English AND 2005/01/012017/11/31 AND risk OR clinical trial, phase III OR controlled clinical trial OR observational study OR RCT or case reports or practice guideline or editorial or review. References of relevant original research as well as review articles were handsearched to identify further studies.

Two investigators (A. L. and A. T.) independently examined all titles and abstracts and obtained full texts of potentially relevant papers. The included articles were reviewed in full and data on the study setting and methodology, characteristics of the populations studied, risk estimate, pathogens and antibiotic treatments were extracted. 


\section{Risk of developing CAP by drug type}

The most studied drugs that increase the risk of pneumonia are the inhaled corticosteroids (ICSs), the Proton pump inhibitors (PPIs), the oral antipsychotics and antidiabetics agents. There are references about the potential role of diuretics, digoxin, $\mathrm{N}$-acetylcysteine, any vitamin intake and oral anticholinergic agents $(11,13)$ in the development of pneumonia. But the effect of the abovementioned drugs as potential risk factors for CAP should be confirmed in further studies.

\subsection{Inhaled corticosteroids (ICSs)}

To prevent and treat COPD, combinations of ICS and long-acting $\beta 2$ agonists (ICS/LABA) are recommended based on evidence from studies such as TORCH and INSPIRE $(14,15)$. However, recent results from the FLAME study have raised doubts about this strategy (16). In patients with COPD, RCTs (17-22), meta-analyses (23-27), and observational studies (28-34) have generally observed an increased risk for pneumonia associated with the use of ICS-containing medication (Table 1).

\section{Randomized controlled trials (RCTs)}

The impact of ICS on pneumonia was unexpectedly documented in the TORCH study, which was designed to assess the benefits of inhaled drugs on long-term survival in COPD patients (14). The TORCH study revealed an increased risk for pneumonia in COPD patients treated with fluticasone (FC) (HR, 1.52; 95\% confidence interval (CI): 1.32-1.76) alone and in combination with salmeterol (SAL). The incidence of pneumonia increased significantly in patients treated with FC alone (18.3\%) or in combination with SAL (19.6\%) compared to patients treated with placebo (12.3\%) (35).

Similarly, Crim et al. (20), in a post -hoc analysis of TORCH study, analysed and identified potential risk factors for adverse event reports of pneumonia noted an approximately $50 \%$ increase in the risk for pneumonia $(\mathrm{HR}, 1.52 ; 95 \% \mathrm{Cl}$ : 1.32-1.76) among those treated with fluticasone propionate (FP) compared to those on placebo.

In a 12-month RCT involving 1,219 patients with severe FEV1 of $<50 \%$, Sharafkhaneh et al. proved that BUD presented a dose-related risk for pneumonia (22). The incidence of pneumonia was higher in the BUD/F pMDI groups than in the $F$ group, as well as in the $320 / 9 \mathrm{mg}$ BUD/F pMDI group than in the $160 / 9 \mathrm{mg}$ BUD/F pMDI group (6.4\% vs. $4.7 \%$ vs. $2.7 \%$, respectively).

In a cohort of 163,514 patients (21), of whom 20,344 had a serious case of pneumonia during the 5.4 years of follow-up (incidence rate 2.4/100/year), current use of /CS was associated with a $69 \%$ increase in the incidence of serious pneumonia (RR, 1.69; $95 \% \mathrm{Cl}: 1.63-1.75)$. The risk continued with long-term use and declined gradually after stopping ICS treatment, disappearing after 6 months (RR, 1.08; $95 \% \mathrm{Cl}$ : 0.99-1.17). The incidence of serious pneumonia was higher for FC (RR, 2.01; 95\% Cl: 1.93-2.10), increasing with the daily dose, but much lower for budesonide (BUD) (RR, 1.17; $95 \% \mathrm{Cl}: 1.09-1.26)$.

Similarly, one year ago, a secondary analysis of the large UPLIFT study revealed that the incidences of pneumonia were significantly higher in patients taking ICS than in those not on ICS (0.068 vs. 0.056 , respectively; $p=0.012)$, with the patients on FC showing a higher rate of pneumonia than those on other types of ICSs (0.077 vs. 0.058 , respectively; $p<$ $0.001)(31)$.

However, as a previous study of Mapel et al (33), a very recently published RCT did not observe an increased risk for pneumonia with ICS treatment (vilanterol $25 \mu \mathrm{g}(\mathrm{VI})$, fluticasone furoate $100 \mu \mathrm{g}$ (FF), vilanterol $25 \mu \mathrm{g}$ combined with 100 $\mu \mathrm{g}$ fluticasone furoate (FF/VI), or matched placebo) in COPD subjects with moderate airflow limitation and heightened cardiovascular risk (34).

Likewise, Festic et al. (36) performed a secondary analysis of an established database ( $n=5584$ ) from a lung injury study (LIPS), to evaluate the possibility that prehospital ICS use predisposes COPD patients to pneumonia. After adjusting for multiple confounders, the adj OR for participants with COPD was $1.40(95 \% \mathrm{Cl}, 0.95-2.09)$ and was not statistically significant $(p=0.93)$.

\section{Observational studies}

The association between ICS use and pneumonia has also been examined in population-based cohort studies of COPD. Starting, a case-control epidemiological study in Canada (28) published in 2007, compared the rates of ICS use in elderly COPD patients who were hospitalized due to pneumonia with those in 95,768 controls. ICS use was associated with a dose-dependent increased risk for hospitalization due to pneumonia (RR, 1.70; 95\% Cl: 1.63-1.77) and increased pneumonia-related mortality at 30 days ( $R R, 1.53 ; 95 \% \mathrm{Cl}: 1.30-1.80)$. The rate ratio of hospitalization due to 
pneumonia was the highest with the largest doses of ICS used, which was equivalent to $1,000 \mu \mathrm{g} / \mathrm{day}$ or more of FC (RR, $2.25 ; 95 \% \mathrm{Cl}: 2.07-2.44)$.

Müllerova et al. (7) examined the risk of CAP in a cohort of 40,411 COPD patients. The authors showed that patients with COPD who were treated with an ICS were more likely to develop CAP. In an observational cohort study from the UK, ICS-containing medication administered to new users was associated with an increased risk for hospitalization due to pneumonia (HR, 1.55; 95\% Cl: 1.14-2.10) and for pneumonia ( $\mathrm{HR}, 1.49 ; 95 \% \mathrm{Cl}: 1.22-1.83)$. The increased risk for pneumonia decreased for treatments with ICS lasting $>1$ month or $>6$ months in the new users. There was also an apparent dose-related effect, with higher daily doses of ICSs (32).

The varying levels of risk associated with the different types of ICSs was also apparent in the PATHOS study (29), which revealed that the rates of pneumonia and hospital admissions were higher in patients treated with $\mathrm{FC} / \mathrm{SAL}$ (rate ratios of 1.73 (95\% Cl: $1.57-1.90 ; \mathrm{p}<0.001)$ and 1.74 (95\% Cl: 1.56-1.94; $\mathrm{p}<0.001)$, respectively) than in those on BUD/ formoterol (F). However, the study had some limitations as the majority of the fixed-dose treatments prescribed were BUD/F (72\%) and the authors compared a high daily dose of FC (783 $\pm 338 \mathrm{mcg} / \mathrm{day})$ to a medium daily dose of BUD (568 $\pm 235 \mathrm{mcg} / \mathrm{day})$, without analyzing equipotent doses and similar time periods.

\section{Meta-analyses}

Several meta-analyses have evaluated the association of ICS use in patients with COPD and the risk of developing pneumonia(2324,25,27).

Drummond et al. (23) identified 11 RCTs of stable COPD patients treated with ICSs, The authors conclude that administration of ICSs is associated with a $34 \%$ increased risk of developing pneumonia, colleagues found a dose- and time-related effect. In a Cochrane meta-analysis that included 43 studies, 26 on FC ( $n=21,247)$ and 17 on BUD ( $n=$ 10,150 ), FC was associated with a higher risk for any type of pneumonia (i.e., less serious cases treated in the community) than BUD (OR, 1.86; 95\% Cl: 1.04-3.34) (25).

Festic et collegues (27), two years ago, performed a meta-analysis of 38 studies: 29 RCTs and 9 observational studies. The estimated unadjusted risk of pneumonia was increased in RCTs: RR 1.61; 95\% Cl 1.35-1.93, p < 0.001 ; as well as in observational studies: OR 1.89; $95 \% \mathrm{Cl} 1.39-2.58, \mathrm{p}<0.001$.

On the contrary, a meta-analysis performed by Sin et al. showed that BUD did not increase the risk for pneumonia in patients with COPD (26).

\subsection{Proton pump inhibitors (PPIs)}

Proton pump inhibitors (PPIs) are among the most widely prescribed medications and are used to provide long-lasting reduction in gastric acid production. They are widely used to prevent the development of ulcers and treat

gastrointestinal diseases, such as dyspepsia, peptic ulcer disease, gastroesophageal reflux disease, Barrett's esophagus, and stress-induced gastritis. In 2011, omeprazole was the sixth most commonly prescribed drug in the United States with nearly 60 million prescriptions (37). Additionally, it has been reported that in approximately $40 \%$ of older adult long-term PPI users, there is no indication for PPI use (38).

Observational studies and a few RCTs in the last decade have yielded inconsistent findings about the association between PPI use and the risk for pneumonia. This side effect of PPIs is clearly time dependent as indicated by the studies mentioned below (Table 2).

RCTS

Sugano et al (39) in a RCT involving 99 sites in Japan for 1 year, was designed to compare the efficacy of lansoprazole (15 mg daily) with gefarnate (50 mg twice daily) in patients with a history of gastric or duodenal ulcers who required long-term NSAID therapy. In the case of pneumonia, a causal relationship with the study medication was denied in all patients in this study.

\section{Observational studies}

A large population study from the Netherlands (40) analyzed a cohort of occasional users of PPIs and found the incidence of pneumonia to be 2.45 per 100 individuals per year.

Gulmez et al. in 2007 reported an increased risk for CAP in the general population (OR, 1.5; 95\% Cl: 1.3-1.7) among PPI users, but not among those taking $\mathrm{H}_{2}$-receptor antagonists $\left(\mathrm{H}_{2} \mathrm{RA}\right.$ ) (adjusted $\mathrm{OR}, 1.10 ; 95 \% \mathrm{Cl}$ : 0.8-1.3) (41). The authors stated that the recent initiation of PPI treatment (0-7 days prior to a CAP episode) resulted in a strong association with the risk for CAP (OR, 5.0; 95\% Cl: 2.1-11.7). However, neither a dose-response relationship nor a cumulative effect was 
found. Similarly, Myles et al. (42) reported that current PPI prescriptions were associated with a significantly increased risk for pneumonia of nearly $55 \%$ in a large population-based case-control study of 3,709 pneumonia cases and 22,174 controls (adjusted OR, 1.55; 95\% Cl: 1.38-1.77).

Accordingly, a large population-based case-control study using primary care data from the UK reported that newlydiagnosed CAP cases increased with the current use of PPIs (RR, 1.16;95\% Cl: 1.03-1.31), but not $\mathrm{H}_{2} \mathrm{RA}$ (RR, 0.98; 95\% $\mathrm{Cl}: 0.80-1.20)$. However, an increased risk for pneumonia was evident only in the first 12 months of PPI treatment, with some evidence of a dose response (43). Sarkar et al. (44) reported that, overall, current PPI use was not associated with an increased risk for pneumonia (OR, 1.02; $95 \% \mathrm{Cl}$ : 0.97-1.08); this association only occurred when PPI therapy had been started in the previous 30 days (OR, 1.96; 95\% Cl: 1.69-2.29). Additionally, there were no associations between CAP and $\mathrm{H}_{2} \mathrm{RA}$ treatment and between CAP and PPI administered to adults $>60$ years old.

A recently published large population-based study from Taiwan, which included 1,572 dementia patients, identified PPI use to be an independent risk factor for pneumonia (45). Interestingly, PPIs were found to double the risk for CAP in a dose-dependent manner.

PPI-associated increases in susceptibility to respiratory infections are likely to be due to the PPI-mediated increases in gastric $\mathrm{pH}$, which promotes bacterial colonization and transfer to the respiratory system. However, in contrast to PPIs, $\mathrm{H}_{2} \mathrm{RAs}$ have not been associated with an increased risk for pneumonia $(41,42,43)$. This difference might reflect the higher potency of PPIs compared to $\mathrm{H}_{2} \mathrm{RAs}$. Moreover, Walentek et al. (46) indicated that PPI-associated pneumonia in human patients might, at least in part, be linked to the dysfunction of the mucociliary epithelia of the airways. However, a case-control study performed in the US in older adults concluded that the current use of PPI and $\mathrm{H}_{2} \mathrm{RA}$ was not associated with an increased risk for CAP (adjusted OR, 1.03; 95\% Cl: 0.86-1.24) in a fully adjusted analysis (47). When the association between CAP and PPI use by indication was analyzed, the authors of the study observed a greater increase in risk among patients taking these medications for peptic ulcers or dyspepsia than among those taking the drugs for gastroprotection or gastroesophageal reflux disease.

\section{Meta-analysis}

Johnston et al ( 48 ) in a meta-analysis of 6 nested case-control studies, found an increased risk of CAP associated with PPI use [OR 1.36 (95\% Cl 1.12-1.65)]; significant heterogeneity remained (I2 92\%, P < 0.001). Eom and colleagues (49) conducted a meta-analysis of eight observational studies and found that PPI use was associated with a $27 \%$ increased risk for either hospital-acquired pneumonia (HAP) or CAP (adjusted OR, 1.27; 95\% Cl: 1.11-1.46). An increased risk for CAP with PPI use was also observed when only five of the studies were analyzed (adjusted OR, 1.34; 95\% Cl: 1.14-1.57). Importantly, there was a strong temporal effect, with treatments of $<7$ days being associated with a three-fold increase in the risk for pneumonia (adjusted OR, 3.95; $95 \% \mathrm{Cl}: 2.86-5.45$ ). Several years later, Lambert et al. (50) analyzed 26 studies involving a total of 226,769 CAP cases among 6,351,656 participants. They observed a pooled risk for CAP with ambulatory PPI therapy of 1.49 (95\% Cl:1.16-1.92), which increased during the first month of treatment (OR, 2.10; $95 \%$ $\mathrm{CI}: 1.39-3.16)$, regardless of PPI dose or the age of the patient. Of note, this meta-analysis did not find an association between the risk for CAP and $\mathrm{H}_{2} \mathrm{RA}$ treatment (OR, 1.00; 95\% $\mathrm{Cl}: 0.90-1.12$ ).

On the contrary, Filion et al (51) formed eight restricted cohorts of new users of NSAIDs, and after meta-analysis, support that PPIs are not associated with an increased risk of hospitalization for CAP (adjOR=1.05; $95 \% \mathrm{Cl} 0.89$ to 1.25 ).

\subsection{Antipsychotic agents}

Antipsychotic drugs (APs) are generally categorized as typical antipsychotic drugs (TAPs), such as butyrophenones (e.g., haloperidol) and phenothiazines (e.g., thioridazine), or the newer class of atypical antipsychotic drugs (AAPs), such as clozapine, risperidone, olanzapine, and quetiapine. Antipsychotics are primarily indicated in the treatment of schizophrenia and the manic phases of bipolar disorder. However, these drugs are also frequently used off-label. In recent years, antipsychotics have been increasing used worldwide to treat the behavioral and psychological symptoms of dementia (BPSD). According to the 2004 National Nursing Home Survey, one in four elderly nursing home residents in the USA had received APs, with $94.5 \%$ receiving AAPs (52).

In June 2008, the FDA warned about the increased risk for all-cause mortality in elderly patients with dementia treated with TAPs (53), the usual causes of death being heart-related events and infections (primarily pneumonia). In Europe, the UK Department of Health commissioned the National Dementia and AP Prescribing (DAP) audit, which suggested a reduction in AP prescribing by half between 2008 and $2011(54,55)$. With the safety warnings there was a sustained 25 $\%$ reduction in AP use between 2010 and 2012 in the UK (from a quarterly prevalence of 14 to $11 \%$ ), whereas a 
substantial increase in total AP use (to $32 \%$ in 2012) was observed in Italy.

Data from several studies, mainly in elderly patients, suggest that the use of APs is associated with a moderate increase in the risk for CAP (56-59). Trifiró et al (57) used a nationwide general practice database to investigate fatal and nonfatal pneumonia and discovered that the use of either AAPs or TAPs in elderly patients was associated with an increased risk for CAP in a dose-dependent manner. No clear pattern between the risk for CAP and treatment duration has been found to date, although two studies have observed the risk to be highest during the early phase of treatment with APs $(10,57)$. Moreover, Knol et al. (58) observed a $60 \%$ increased risk for pneumonia during the first week of treatment with 'anti-psychotic' medication, the greatest increase in risk being found for the AAPs. By contrast, Aparasu et al. (59) found no differences in the risk for pneumonia between TAPs and AAPs in a retrospective cohort of 49,904 new users of APs among eligible nursing home residents.

Gambassi et al. (60), estimating the risk-benefit ratio for prescribing APs, suggested that there was 1 hospitalization for pneumonia for every 2-5 patients showing any clinical improvement in symptoms in response to treatment with APs. In a nested case-control study that followed patients aged 18-65 years with schizophrenia over eight years, Kuo et al. (61) found that the use of second-generation antipsychotic drugs was associated with a $69 \%$ greater risk (adjusted RR $=1.69$ ) of developing pneumonia, after taking into account confounding factors, with the magnitude of the association being the highest for clozapine. Although quetiapine, olanzapine, zotepine, and risperidone were also associated with an increased risk, there was no clear dose-dependent association. Wang et al. (62) reported that the risk for pneumonia was the highest within the first 30 days of treatment with APs (HR, 1.1; 95\% Cl: 0.76-1.38), decreasing after 60 days (HR, 1.03; 95\% Cl: 0.76-1.38) and disappearing after 120 days of treatment (HR, 0.84; 95\% Cl: 0.66-1.05). Likewise, Trifiró and colleagues (57) demonstrated that the risk for CAP lasted only in the first week of treatment (OR, 4.62; $95 \% \mathrm{Cl}: 2.05$ 10.38), decreasing thereafter. Similarly, Pratt et al. (63) observed a reduced risk with continuous treatment in a selfcontrolled case series, but only for AAPs.

Different levels of risk have been reported for the different types of antipsychotic drugs $(57,64)$, with risperidone shown to be associated with the highest risk for pneumonia (OR, 3.51;95\% Cl: 1.94-6.36). Furthermore, a large population-based study assessing 92,234 new users of AAPs suggested that risperidone (HR, 1.14; $95 \% \mathrm{Cl}: 1.10-1.18$ ) and olanzapine (HR, 1.10; $95 \% \mathrm{Cl}: 1.04-1.16)$ increased the risk for pneumonia in elderly patients compared to quetiapine (65).

Although it is highly possible that the sedative and anticholinergic side effects of the APs could increase the risk of aspirations by decreasing peristalsis, the exact mechanisms by which APs increase the risk for CAP are unclear and remain speculative (10). There is minimal risk for akinesia with AAPs, particularly when these drugs are used at low doses (66).

\subsection{Oral antidiabetic agents}

There are increased incidences of pneumonia, associated complications, and mortality among patients with diabetes (67). Like glucocorticoids in COPD, the immunomodulatory and glucocorticoid-like properties of antidiabetic drugs such as thiazolidinediones could increase susceptibility to lung infections.

There are a number of different types of antidiabetic drugs belonging to different classes as: biguanides (metformin), sulfonylureas (glipizide,glyburide,tolbutamide), thiazolidinediones (pioglitazone) and GLP-1 receptors agonists (exenatide, liraglutide). Dipeptidyl-peptidase-4 inhibitors (DPP4Is) (sitagliptin, saxagliptin, vildagliptin, linagliptin and alogliptin) are a new class of drugs for the treatment of type 2 diabetes mellitus (T2DM). Some drugs are combinations of some of these drug types.

\section{Observational studies}

A study that used data from the World Health Organisation's Adverse Drug Reactions database found a 12-fold increased risk of URTI among DPP4I users versus users of biguanides (68).(Table 4)

In a population-based cohort study (69) using data from the world's largest primary care database, the UK Clinical Practice Research Datalink (CPRD), including 211,049 NIAD users, current users of NIADs had a 1.6-fold increased risk of pneumonia, as compared with nondiabetic controls (adj. HR 1.56 ; [Cl] 1.42-1.71). The risk of pneumonia was not increased with current DPP4I use versus use of other NIADs, [(HR) 0.70; 95\% (CI) 0.55-0.91]). There was no further significant dose-effect relationship between pneumonia and DPP4I use. Accordingly, an observational study carried out in the UK found no association between the use of DPP-4 inhibitors and the risk of hospitalization from CAP [adj(OR) $0.80 ;(0.50-1.29)](70)$. 
However, there are differences in the level of risk for pneumonia among drugs from the same category. A recent cohort study using a Danish nationwide population database (71) involving 131,949 patients with T2DM showed that those who had started treatment with sulfonylureas had a slightly or a substantially higher risk for hospitalization caused by pneumonia than those who had initiated treatment with metformin $(H R, 1.12 ; 95 \% \mathrm{Cl}: 1.08-1.16)$ or insulin $(H R, 1.63$; 95\% Cl: 1.54-1.72), respectively.

Gorricho et al. (72) in a case-control study reported that the use of any combination involving thiazolidinediones was associated with a higher risk for CAP (adjusted OR, 2.00; 95\% CI: 1.22-3.28), which was double the risk associated with metformin plus sulfonylurea treatment.

\section{Review and Meta-analysis}

The higher rate of chest infections among diabetic patients after being prescribed antidiabetics is in line with a Cochrane review of short-term clinical trials (<6 months) (73) that demonstrated a strong association between orally active DPP-4 inhibitors, like sitagliptin, and pneumonia. Vildagliptin was also associated with an increased incidence of infections, but this did not reach statistical significance.

7

Singh et al. (75) performed a systematic review and meta-analysis of 13 trials ( $n=17,627$, of whom 8,163 were patients with type 2 diabetes receiving thiazolidinediones and 9,464 were patients receiving control therapy) that had follow-up periods of 1-5.5 years. They reported that long-term thiazolidinedione use was associated with the risk of developing serious pneumonia or lower respiratory tract infections (RR, 1.42; 95\% CI: 1.09-1.84; $p=0.009$ ). The use of DPP-4 inhibitors was not associated with an increased risk for CAP.

But Gooben et al (74) in a systematic review and meta-analysis of 39 RCTs with DPP4Is in diabetic patients $(n=18,491$, comparator mostly placebo), did not show an increased risk of all-cause infection (relative risk $(\mathrm{RR})=0.98(95 \% \mathrm{Cl} 0.93-$ $1.05)$ ) or URTS s (RR $=0.97$ (95\% $0.83-1.14)$. Similarly, a pooled analysis of 25 clinical studies $(n=14,611)$ with sitagliptin vs. comparator (mostly placebo) in T2DM patients, showed no increased risk of pneumonia (difference in incidence rate (IR) per 100 patient years between sitagliptin and comparator 0.2 ( $95 \% \mathrm{Cl}-0.2$ to 0.5$)$ (75).

Eventually, large epidemiological databases can be useful tools to evaluate the association of specific antidiabetic drugs with the incidence of CAP, as have shown with other medications(for example PPIs).

\section{Summary}

This review confirms that treatment with ICSs, PPIS, AAPs, or some oral antidiabetic drugs increases the risk for pneumonia. Use of either TAPs or AAPs is associated with a two- to three-fold increased risk for pneumonia in a dosedependent manner, with AAPs often associated with a higher risk for pneumonia compared to conventional agents. The frequent use of PPIs, especially in the elderly population, has been linked to an increased risk for pneumonia in a timedependent manner. Meanwhile, there is now a body of evidence that links ICS use to pneumonia, especially in COPD patients, in a dose-related way, although this is not associated with mortality. Given the potential risk for pneumonia, clinicians should exercise caution when prescribing these drugs for patients with specific indications.

\section{Expert opinion}

This review provides a comprehensive compilation of data on the risk of developing pneumonia when taking pharmacotherapeutic agents for specific comorbidities.

(1) An increased risk for pneumonia with ICS use in COPD has been reported in both RCTs and observational studies. Despite the number of studies reporting this association, there are still many unresolved issues regarding the link between ICS use and pneumonia in patients with COPD (e.g., class effect, dose effect, influence on mortality, and underlying mechanisms). One possible explanation for the ICS-associated increased risk for pneumonia is that the combination of impaired macrophage function and an altered respiratory microbiome might provide conditions in the lung that favor the development of pneumonia.

Despite these many observations, lingering questions remain. There are doubts about the true incidence of this event in the trials. Is ICS use and pneumonia real or an epiphenomenon (ie, are patients who have more severe COPD and use ICSs more frequently more likely to experience pneumonia simply because of their baseline COPD)?

Moreover, the studies discussed in this review had several methodological limitations; were largely focused on pneumonia events documented as adverse events not as primary outcome ; not using predefined diagnostic radiographic criteria for pneumonia and not including head-to-head comparisons of the different types of ICS (77). 
Indeed, the European Medicines Agency's Committee for Medicinal Products for Human Use has stated that there is no difference in the risk for respiratory adverse events for the different classes of ICSs (78).

The benefits of COPD therapy that counterbalance any associated risks may change with time. According to global guidelines for COPD treatment, ICS in combination with a LABA is appropriate for patients with a higher risk for COPD, defined as GOLD stage 3 or 4, and/or frequent exacerbations (79).

Strategies to reduce the risk for pneumonia in COPD patients include withdrawing or reducing the dose of the ICS. As WISDOM study recommend ICS withdrawal is safe if patients are maintained on maximum bronchodilator therapy (80). The need for long-term corticosteroid therapy or using it at a minimally effective dose should be re-evaluated. The identification of specific risk factors for pneumonia could provide a more accurate risk-benefit assessment of ICS treatment in COPD patients. Among the COPD patients treated in the UK, the incidence of CAP is increased in specific subpopulations, particularly those with older age, greater COPD severity, prior CAP episodes, and certain co-morbid conditions (81).

Identifying markers of clinical response to ICSs, such as sputum eosinophils, might enable the targeting of ICS to COPD patients who will benefit, thereby reducing the overall incidence of adverse effects such as pneumonia $(77,82)$. It is quite difficult to understand the real magnitude of the side effects induced by ICSs given that COPD is associated with several comorbidities, although the role of ICS must always be taken into account.

During the 5 years of follow-up in a case-control study published in 2013, 123 out of 870 (14\%) current ICS users had recurrent pneumonia compared to 395 out of 4,603 (9\%) participants who had never used ICS (adjusted OR, 1.90; 95\% $\mathrm{Cl}: 1.45-2.50 ; \mathrm{p}<0.001$; number needed to harm $=20)(83)$.

Observational studies $(81,84,85)$ and meta-analyses $(25,27)$ have also shown no significant increases in pneumoniarelated mortality in ICS users probably due to reduced non-specific inflammation and decreased neutrophil influx into the lungs. In any case, there is an obvious need for prospective trials to define the dose-dependent risk for pneumonia associated with ICSs and whether the risk varies between the different ICSs.

(2) The association between the use of atypical antipsychotics and the risk for CAP has been explored by epidemiological cohort and case-control studies (86). Antipsychotic drugs are associated with an increased risk for fatal or non-fatal pneumonia in a dose-dependent manner, the risk being high soon after the beginning of treatment (57). Antipsychotic drugs with a higher affinity for histamine $\mathrm{H} 1$ receptors are linked to an increased risk for pneumonia. The varying antihistaminergic and muscarinic effects of the different APs may play a major role in the relative risk profile of developing pneumonia. For example, olanzapine has been reported to show a higher affinity for histaminergic and muscarinic receptors than quetiapine $(57,87)$.

In the review of Sultana et al two targets, thromboxane A2 receptor (TBXA2R) and platelet activating factor receptor (PTAFR) were found to be novel AP target receptors potentially associated with pneumonia in relation to the antipsychotics (88). Biological pathways constructed using Cytoscape identified plausible biological links potentially leading to pneumonia downstream of TBXA2R and PTAFR.

It is difficult to explore the relationship between antipsychotics and pneumonia since patients with dementia already have a higher risk for aspiration pneumonia. The methodological issue protopathic bias, as delirium is a prodromal symptom of pneumonia for which antipsychotics may be prescribed; therefore, antipsychotic use may appear to be associated with pneumonia, but in reality, is not. Additionally, most studies investigated APs by class rather than by individual drug, with a few exceptions.

As pneumonia associated with antipsychotic medication in elderly patients is more likely to occur at higher dosages, it is important to start therapy with the lowest dosage possible, followed by careful dose titration. The risk seems to peak at the beginning of treatment (e.g., 7-30 days) and dissipates over time for both conventional and atypical APs.

The increased risk for pneumonia not only applies to elderly individuals, but also to younger patients, although more data are required to confirm the latter. Subgroup analysis failed to show significant differences in the risk for pneumonia between patients with psychiatric diagnoses (schizophrenia and bipolar disorder) and those with mainly cognitive impairment or dementia (88).

In general, the lowest possible dose of antipsychotics should be prescribed. Whenever possible, concomitant administration of antipsychotics with other neuropsychiatric drugs that have a sedative effect (i.e., opioids and benzodiazepines) or anticholinergic properties (i.e., tricyclic antidepressants) should be discouraged or limited to short periods with careful observation.

Further research should provide more details on individual antipsychotics, doses with the lowest risk for developing pneumonia, and the role of the severity of dementia and other possible risk factors as functionality status of the 
patients (mobility, dressing and

accommodation ) in the association between antipsychotic medication and pneumonia (89).

(3) Observational studies and meta-analysis demonstrate a positive association between PPI use and the risk of CAP. As Eom et al. (49) reported in their meta-analysis, the most striking increase in the PPI-associated prevalence of pneumonia was observed in the first week of PPI use, with about one case of hospitalized pneumonia observed in every 200 patients on PPIs.

PPI therapy may lead to pneumonia both through acute $\mathrm{pH}$ dysregulation and alteration of the gut microbiome. The risk for pneumonia is the highest during the first month of therapy, which is the time during which the aerodigestive microbiome might be in greatest flux (90). De Jager et al. concluded that PPI therapy was associated with an approximately two-fold increased risk of developing CAP, possibly as a result of S. pneumoniae infection (91). However, a study of the causative microorganism of CAP in patients receiving PPIs did not show an increase in the frequency of either oropharyngeal or gastrointestinal bacteria (92). Another possible explanation could be the immunomodulatory effects of PPIs. Omeprazole and lansoprazole have been shown to inhibit the expression of adhesion molecules on neutrophils, indicating that PPIs may reduce adequate transmigration of leukocytes to sites of inflammation (92). Future studies should employ a rigorous definition of CAP and assess various doses and durations of PPI treatment to further explore the association between PPI use and CAP in specific populations.

\section{Conclusion}

Treatment with ICSs, PPIs, and antipsychotics, especially atypical antipsychotic drugs, is associated with the risk of developing pneumonia. An increased risk for pneumonia with ICS use in COPD was first described in 2007 and has been subsequently reported in RCTs, observational studies, and meta-analyses. Paradoxically, ICS use is associated with reduced mortality in COPD. Regarding antipsychotic medication, the risk for pneumonia is similar among different age groups, increasing in a dose-dependent manner and in the early phases of treatment for both typical and atypical antipsychotic drugs. Given the morbidity and mortality associated with CAP and the extent of PPI use, identification of any risk associated with PPI use is critical for risk stratification and modification where possible. The association of oral antidiabetics with pneumonia needs to be further examined. The current review provides clinical information that can be used to establish preventive interventions for CAP in adults, especially with regards to prescribed drugs.

\section{Funding}

This paper was not funded. 


\section{Declaration of interest}

The authors have no relevant affiliations or financial involvement with any organization or entity with a financial interest in or financial conflict with the subject matter or materials discussed in the manuscript. This includes employment, consultancies, honoraria, stock ownership or options, expert testimony, grants or patents received or pending, or royalties.

\section{Reviewer disclosures}

Peer reviewers on this manuscript have no relevant financial or other relationships to disclose.

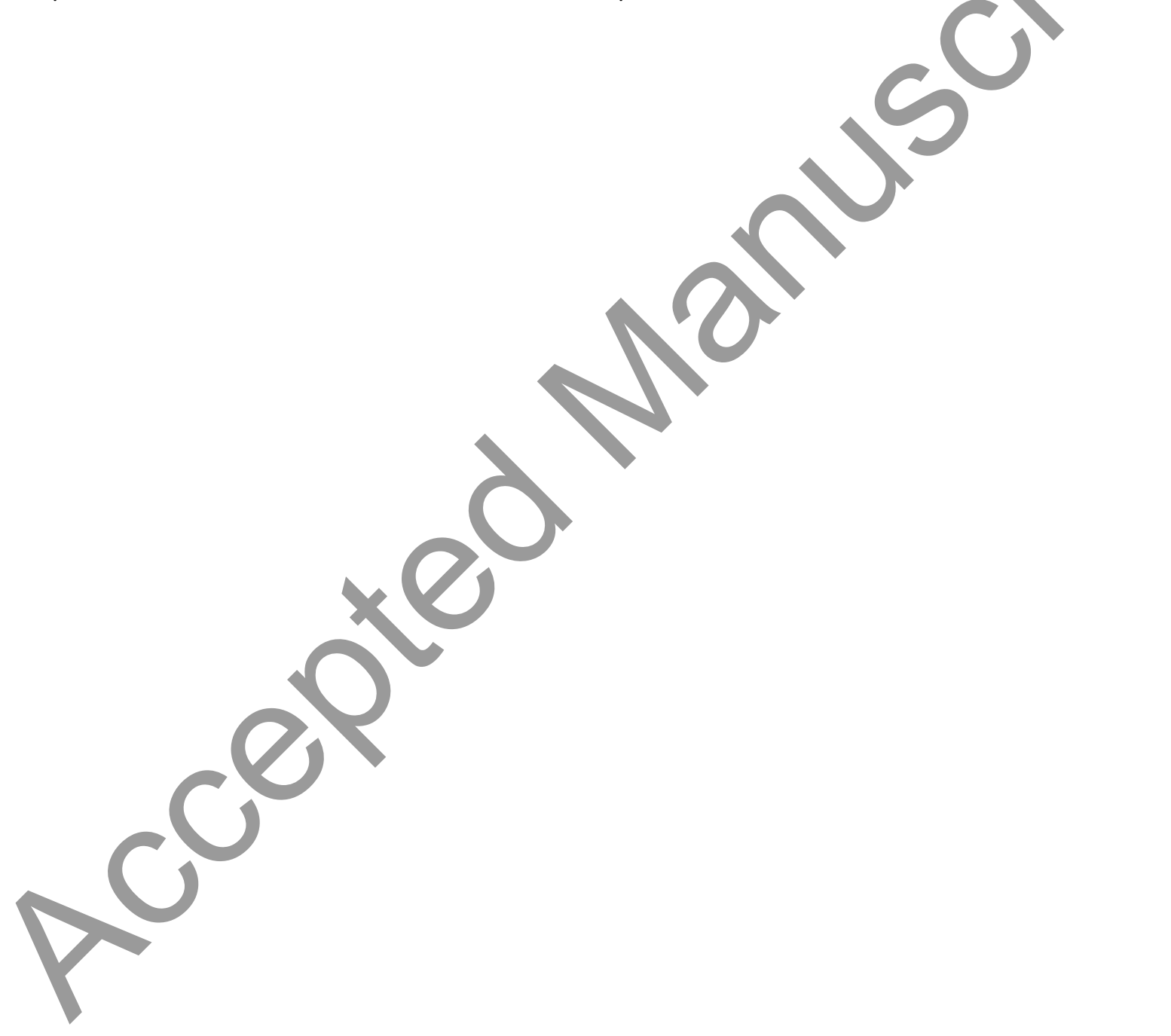




\section{References}

Papers of special note have been highlighted with annotations of their importance.

1. Welte T, Torres A, Nathwani D (2012). Clinical and economic burden of community-acquired pneumonia among adults in Europe. Thorax 67:71-79.

2. James Chalmers, James Campling, Gillian Ellsbury, et al. Community-acquired pneumonia in the United Kingdom: a call to action. Chalmers et al. Pneumonia (2017) 9:15.

3. Bruns AH, Oosterheert JJ, Cucciolillo MC, et al. Cause-specific long-term mortality rates in patients recovered from community-acquired pneumonia as compared with the general Dutch population. Clin Microbiol Infect. 2011; 17: 763-8.

4. Almirall J, Serra-Prat M, Bolíbar I, Balasso V. Risk Factors for Community-Acquired Pneumonia in Adults: A Systematic Review of Observational Studies. Respiration.2017; 94(3): 299-311.

5. Antoni Torres, Willy E Peetermans, Giovanni Viegi, Francesco Blasi. Risk factors for community-acquired pneumonia in adults in Europe: a literature review. Thorax 2013; 68:1057-1065.

6. Farr BM, Woodhead MA, Macfarlane JT, et al. Risk factors for community-acquired pneumonia diagnosed by general practitioners in the community. Respir Med. 2000; 94(5): 422-7.

7. Müllerova H, Chigbo C, Hagan GW, et al. The natural history of community-acquired pneumonia in COPD patients: a population database analysis. Respir Med. 2012 Aug; 106(8): 1124-33.

8. Mannino DM, Davis KJ, Kiri VA. Chronic obstructive pulmonary disease and hospitalizations for pneumonia in a US cohort. Respir Med. 2009;103(2):224-9.

9. Bosch AA, Biesbroek G, Trzcinski K, et al. Viral and bacterial interactions in the upper respiratory tract. PLoS Pathog. $2013 ; 9(1)$ :e1003057.

10. Gau JT, Acharya U, Khan S, et al: Pharmacotherapy and the risk for community-acquired pneumonia. BMC Geriatr 2010; $10: 45$.

11. Paul KJ, Walker RL, Dublin S: Anticholinergic medications and risk of community- acquired pneumonia in elderly adults: a population- based casecontrol study. J Am Geriatr Soc 2015; 63: 476-485.

12. Decramer M, Rutten-van Mo“lken M, Dekhúijzen PN, et al. Effects of N-acetylcysteine on outcomes in chronic obstructive pulmonary disease (Bronchitis Randomized on NAC Cost-Utility Study, BRONCUS): a randomized placebo-controlled trial. Lancet 2005; 365: $1552-1560$.

13. Almirall J, Bolíbar I, Serra-Prat M, et al. Community-Acquired Pneumonia in Catalan Countries (PACAP) Study Group. New evidence of risk factors for community-acquired pneumonia: a population-based study. Eur Respir J. 2008 Jun;31(6):1274-84.

14. Calverley PM, Anderson JA, Celli B, et al. Salmeterol and fluticasone propionate and survival in chronic obstructive pulmonary disease. $\mathrm{N}$ Engl $\mathrm{J}$ Med 2007; 356: 775-789.

An analysis of the TORCH trial, included 6112 patients with COPD, demonstrated that all-cause mortality rates were not different regarding inhaled medications: $12.6 \%$ in the combination-therapy group, $15.2 \%$ in the placebo group, $13.5 \%$ in the salmeterol group, and $16.0 \%$ in the fluticasone group. The probability of having pneumonia reported as a adverse event was higher among patients receiving medications containing fluticasone propionate.

15. Wedzicha JA, Calverley PM, Seemungal TA,; INSPIRE Investigators. The prevention of chronic obstructive pulmonary disease exacerbations by salmeterol/fluticasone propionate or tiotropium bromide. Am J Respir Crit Care Med. 2008 Jan 1; 177(1):19-26. 
An RCT including 1,323 patients to compare the relative efficacy of the long-acting inhaled bronchodilator/antiinflammatory combination (salmeterol/fluticasone propionate) 50/500 microg twice daily and the long-acting bronchodilator (tiotropium) 18 microg once daily in preventing exacerbations and related outcomes in severe and very severe COPD.

16. Wedzicha JA, Banerji D, Chapman KR, et al. Indacaterol-glycopyrronium versus Salmeterol-fluticasone for COPD. N Engl JMed 2016; 374(23): 22222234.

17. Anzueto A, Ferguson GT, Feldman G, et al. Effect of fluticasone propionate/salmeterol (250/50) on COPD exacerbations and impact on patient outcomes. COPD 2009; 6 320e9.

18. Peter Kardos, Marion Wencker, Thomas Glaab, and Claus Vogelmeier . Impact of Salmeterol/Fluticasone Propionate versus Salmeterol on Exacerbations in Severe Chronic Obstructive Pulmonary Disease Am J Respir Crit Care Med Vol 175, pp 144-149, 2007

19. Vogelmeier CF, Bateman ED, Pallante J, et al. Efficacy and safety of once-daily QVA149 compared with twice-daily salmeterol-fluticasone in patients with chronic obstructive pulmonary disease (ILLUMINATE): a randomised, double-blind, parallel group study. Lancet Respir Med. 2013 Mar;1(1):5160.

20. Crim C, Calverley PM, Anderson JA, et al. Pneumonia risk in COPD patients receiving inhaled corticosteroids alone or in combination: TORCH study results. J.Eur Respir J. 2009 Sep; 34(3): 641-7

21. Suissa S, Patenaude V, Lapi F, Ernst P. Inhaled corticosteroids in COPD and the risk of serious pneumonia. Thorax $2013 ; 68$ (11): 1029 - 1036.

A RCT included 163,514 COPD patients, of which 20,344 had a serious pneumonia event during the 5.4 years of follow-up. Current use of ICS was associated with a $69 \%$ increase in the rate of serious pneumonia (RR: $1.69 ; 95 \% \mathrm{Cl}: 1.63$ to 1.75 ). The risk was sustained with long-term use and declined gradually after stopping ICS use.

22. Sharafkhaneh A, Southard JG, Goldman M, et al. Effect of budesonide /formoterol pMDI on COPD exacerbations: a double-blind, randomized study. Respir Med 2012; 106: 257-268.

23. Drummond MB, Dasenbrook EC, Pitz MW, et al. Inhaled corticosteroids in patients with stable chronic obstructive pulmonary disease: a systematic review and meta-analysis. JAMA 2008; 300: 2407-216.

24. Singh S, Loke YK. Risk of pneumonia associated with long-term use of inhaled corticosteroids in chronic obstructive pulmonary disease: a critical review and update. Curr Opin Pulm Med 2010;16: 118-122.

An interesting meta-analysis showing that the associated mortality risk with concomitant CAP and COPD is weak and heterogeneous. ICS use was not consistently associated with reduced mortality from pneumonia.

25. Kew KM, Seniukovich A. Inhaled steroids and risk of pneumonia for chronic obstructive pulmonary disease.Cochrane Database SystRev.2014Mar10;(3):CD010115

A Cochrane analysis including budesonide and fluticasone, delivered alone or in combination with a LABA, are associated with increased risk of serious adverse pneumonia events, but neither is significantly affected mortality compared with controls.

26. Don D Sin, Donald Tashkin, Xuekui Zhang, et al. Budesonide and the risk of pneumonia: a meta-analysis of individual patient data. Lancet 2009; 374 : 712-19.

27. Festic E, Bansal V, Gupta E, Scanlon PD. Association of Inhaled Corticosteroids with Incident Pneumonia and Mortality in COPD Patients; Systematic Review and Meta-Analysis. COPD. 2016 Jun; 13(3): 312-26.

28. Ernst $\mathrm{P}$, Gonzalez AV, Brassard P, et al. Inhaled corticosteroid use in chronic obstructive pulmonary disease and the risk of hospitalization for pneumonia. Am J Respir Crit Care Med 2007; 176: 162-166. 
29. Janson C, Larsson K, Lisspers KH, et al. Pneumonia and pneumonia related mortality in patients with COPD treated with fixed combinations of inhaled corticosteroid and long acting $\beta 2$ agonist: observational matched cohort study (PATHOS).BMJ. 2013 May 29; 346:f3306.

Observational retrospective pairwise cohort study from Sweden, including 9893 COPD patients observed comparing with budesonide/ formoterol, rate of pneumonia and admission to hospital were higher in patients treated with fluticasone/ salmeterol: $\mathrm{RR}: 1.73(95 \% \mathrm{Cl} 1.57$ to $1.90 ; \mathrm{p}<0.001)$ and 1.74 (1.56 -- 1.94; $p<0.001)$, respectively.

30. Joo MJ, Au DH, Fitzgibbon ML, Lee TA. Inhaled corticosteroids and risk of pneumonia in newly diagnosed COPD. Respir Med 2010; 104:246e52.

31. Morjaria JB, Rigby A, Morice AH. Inhaled Corticosteroid use and the Risk of Pneumonia and COPD Exacerbations in the UPLIFT Study. Lung. 2017 Jun; 195(3): 281-288.

32. Rachael L. DiSantostefano, Tim Sampson, Hoa Van Le, et al. Risk of Pneumonia with Inhaled Corticosteroid versus Long-Acting Bronchodilator Regimens in Chronic Obstructive Pulmonary Disease: A New-User Cohort Study. PLoS One. 2014 May 30; 9(5): e97149.

A remarkable study that has estimated the association between ICS and pneumonia among new users of ICS relative to inhaled long-acting bronchodilator monotherapy and has documented that ICS are associated with a 20 - 50\% increased risk of pneumonia in COPD, which reduces with exposure time.

33. Mapel D, Schum M, Yood M, et al. Pneumonia among COPD patients using inhaled corticosteroids and long-acting bronchodilators. Prim Care Respir J 2010;19: 109e17.

34. Crim C, Calverley PMA, Anderson JA,; SUMMIT investigators. Pneumonia risk with inhaled fluticasone furoate and vilanterol in COPD patients with moderate airflow limitation: The SUMMIT trial. Respir Med. 2017 Oct; 131:27-34

35. Liapikou A, Toumbis M, Torres A. Managing the safety of inhaled corticosteroids in COPD and the risk of pneumonia. Expert Opin Drug Saf. 2015 Aug; 14(8): 1237-47.

36. Festic E, Bansal V, Gajic O, Lee AS, and the United States Critical IIIness and Injury Trials Group: Lung Injury Prevention Study Investigators (USCIITGLIPS). Prehospital use of inhaled corticosteroids and point prevalence of pneumonia at the time of hospital admission: secondary analysis of a multicenter cohort study. Mayo Clin Proc 2014; 89: 154-62.

37. IMS Institute for Healthcare Informatics. The Use of Medicines in the United States: Review of 2011.2012.

38. Wallerstedt S, Fastbom J, Linke J, et al. Long-term use of proton pump inhibitors and prevalence of disease-related and drug-related reasons for gastroprotection - a population-based study. Pharmacoepidemiol Drug Saf 2017; 26: 9-16.

39. Kentaro Sugano, Teiji Kontani, Shinichi Katsuo, et al. Lansoprazole for secondary prevention of gastric or duodenal ulcers associated with long-term non-steroidal anti-inflammatory drug (NSAID) therapy: results of a prospective, multicenter, double-blind, randomized, double-dummy, activecontrolled trial. J Gastroenterol (2012) 47:540-552.

40. Laheij RJ, Sturkenboom MC, Hassing RJ, et al. Risk of community-acquired pneumonia and use of gastric acid- suppressive drugs. JAMA. 2004; 292: 1955-60.

41. Sinem Ezgi Gulmez, Anette Holm, Henrik Frederiksen, et al. Use of Proton Pump Inhibitors and the Risk of Community-Acquired Pneumonia. A Population-Based Case-Control Study. Arch Intern Med. 2007; 167:950-955.

42. Myles PR, Hubbard RB, McKeever TM, et al. Risk of community-acquired pneumonia and the use of statins, ace inhibitors and gastric acid suppressants: a population-based case-control study. Pharmacoepidemiol Drug Saf. 2009 Apr; 18(4): 269-75.

43. Rodríguez LA, Ruigómez A, Wallander MA, Johansson S. Acid-suppressive drugs and community-acquired pneumonia. Epidemiology. 2009 Nov; 20 (6): 800-6.

44. Sarkar M, Hennessy S, Yang YX: Proton-pump inhibitor use and the risk for community-acquired pneumonia. Ann Intern Med 2008, 149:391-398. 
45. Ho SW, Teng YH, Yang SF, et al. Association of Proton Pump Inhibitors Usage with Risk of Pneumonia in Dementia Patients. J Am Geriatr Soc. 2017 Jul; 65(7): 1441-1447.

46. Walentek P, Beyer T, Hagenlocher C, et al. ATP4a is required for development and function of the Xenopus mucociliary epidermis - a potential model to study proton pump inhibitor-associated pneumonia. Dev Biol. 2015 Dec 15; 408(2): 292-304.

47. Dublin $\mathrm{S}$, Walker RL, Jackson ML, et al. Use of proton pump inhibitors and $\mathrm{H} 2$ blockers and risk of pneumonia in older adults: a population-based case-control study. Pharmacoepidemiol Drug Saf 2010; 19:792-802.

48. J . Johnstone, K. Nerenberg \& M. Loeb. Meta-analysis: proton pump inhibitor use and t the risk of community-acquired pneumonia. Aliment Pharmacol Ther 31, 1165-1177.

49. Eom CS, Jeon CY, Lim JW, et al. Use of acid-suppressive drugs and risk of pneumonia: a systematic review and meta-analysis. CMAJ: Canadian Medical Association journal = journal de l'Association medicale canadienne. 2011; 183(3): 310-9.

50. Allison A. Lambert, Jennifer O. Lam, Julie J. et al. Risk of Community-Acquired Pneumonia with Outpatient Proton-Pump Inhibitor Therapy: A Systematic Review and Meta-Analysis. PLOS ONE | June 4, 2015;10(6):e0128004.

51. Kristian B Filion, Dan Chateau, Laura E Targownik, the CNODES Investigators. Proton pump inhibitors and the risk of hospitalization for communityacquired pneumonia: replicated cohort studies with meta-analysis. Gut $2014 ; 63: 552-558$.

52. Kamble P, Chen H, Sherer J, Aparasu RR. Antipsychotic drug use among elderly nursing home residents in the United States. Am J Geriatr Pharmacother 2008; 6(4): 187-97.

53. U.S. Food and Drug Administration: FDA requests boxed warnings on older class of antipsychotic drugs [news release]. Silver Spring, MD: U.S. Food and Drug Administration; 16 June 2008. Available at www.fda.gov/NewsEvents/ Newsroom /PressAnnouncements /2008/ucm116912.htm. [3 Feb 2015].

54. Sultana J, Fontana A, Giorgianni F, et al. The Effect of Safety Warnings on Antipsychotic Drug Prescribing in Elderly Persons with Dementia in the United Kingdom and Italy: A Population-Based Study. CNS Drugs. 2016 Nov;30 (11):1097-1109.

55. Health and Social Care Information Centre. National Dementia and Antipsychotic Prescribing Audit. 2012. http://www.hscic. gov.uk/catalogue/PUB06624/nati-deme-anti-pres-audi-summ-rep. pdf. Accessed 18 Sept 2014.

56. Barnett MJ, Perry PJ, Alexander B, Kaboli PJ. Risk of mortality associated with antipsychotic and other neuropsychiatric drugs in pneumonia patients. J Clin Psychopharmacol. 2006; 26(2):182-187.

57. Trifirò G, Gambassi G, Sen EF, et al. Association of community-acquired pneumonia with antipsychotic drug use in elderly patients: a nested casecontrol study. Ann Intern Med. 2010 Apr 6; 152 (7): 418-25, W139-40.

The study highlights the risk of pneumonia linked to individual antipsychotics

58. Knol W, Van Marum RJ, Jansen PAF, et al. Antipsychotic Drug Use and Risk of Pneumonia in Elderly People. J Am Geriatr Soc 2008; 56:661-66.

59. Aparasu RR, Chatterjee S, Chen H. Risk of pneumonia in elderly nursing home residents using typical versus atypical antipsychotics. Ann Pharmacother. 11 2013; 47(4):464-474.

The study involved a cohort of patients matched on propensity score.

60. Gambassi G, Sultana J, Trifirò G. Antipsychotic use in elderly patients and the risk of pneumonia. Expert Opin Drug Saf. 2015 Jan;14(1):1-6.

61. Kuo CJ, Yang SY, Liao YT, et al. Second-generation antipsychotic medications and risk of pneumonia in schizophrenia. Schizophr Bull 2013; 39: 648-657.

62. Wang MT, Wang YH, Chang HA, et al. Benzodiazepine and Z-drug use and risk of pneumonia in patients with chronic kidney disease: A populationbased nested case-control study. PLoS One. 2017 Jul 10; 12(7): e0179472 
63. Pratt N, Roughead EE, Ramsay E, et al. Risk of hospitalization for hip fracture and pneumonia associated with antipsychotic prescribing in the elderly: a self-controlled case-series analysis in an Australian health care claims database. Drug Saf. 2011; 34(7): 567- 575.

Systematic review including 44 studies, randomized controlled trials, metaanalyses and published observational studies.

64. Huybrechts KF, Schneeweiss S, Gerhard T, et al. Comparative safety of antipsychotic medications in nursing home residents. J Am Geriatr Soc. 2012 Mar; 60 (3): 420-9.

The largest study of patients on antipsychotics.

65.Mehta S, Pulungan Z, Jones BT, Teigland C. Comparative safety of atypical antipsychotics and the risk of pneumonia in the elderly. Pharmacoepidemiol Drug Saf. 2015 Dec; 24(12): 1271-80.

Large comparative study of new users $>65$ years old of AAPs examined the risk of pneumonia

66.Pierre JM. Extrapyramidal symptoms with atypical antipsychotics: incidence, prevention and management. Drug Saf. 2005; 28:191-208.

67. Lara-Rojas CM, Pérez-Belmonte LM, López-Carmona MD, et al. National trends in diabetes mellitus hospitalization in Spain 1997-2010: Analysis of over 5.4 millions of admissions. Eur J Intern Med. 2018 Aug 9. pii: S0953-6205 (18) 30142-0.

68. Willemen MJ, Mantel-Teeuwisse AK, Straus SM, et al. Use of dipeptidyl peptidase-4 inhibitors and the reporting of infections: a disproportionality analysis in the World Health Organization VigiBase. Diabetes Care. 2011; 34(2): 369-74.

69. Wvan der Zanden R, de Vries F, Lalmohamed A, et al. Use of Dipeptidyl-Peptidase-4 Inhibitors and the Risk of Pneumonia: A Population-Based Cohort Study. PLoS One. 2015 Oct 15;10(10):e0139367.

A population-based cohort study using data from the world's largest primary care database, the UK Clinical Practice Research Datalink (CPRD) and found no increased risk of pneumonia in T2DM patients using DPP4Is compared to T2DM patients using other NIADs.

70.Faillie JL, Filion KB, Patenaude V, et al. Dipeptidyl peptidase-4 inhibitors and the risk of community-acquired pneumonia in patients with type 2 diabetes. Diabetes Obes Metab 2015; 17:379-85.

71.Mor A, Petersen I, Sørensen HT, Thomsen RW. Metformin and other glucose-lowering drug initiation and rates of community-based antibiotic use and hospital-treated infections in patients with type 2 diabetes:a Danish nationwide population-based cohort study. BMJ Open $2016 ; 6$ : e011523.

72.Gorricho J, Garjón J, Alonso A, et al. Use of oral antidiabetic agents and risk of community-acquired pneumonia: a nested case-control study. Br J Clin Pharmacol. 2017 Mar 11; 83(9): 2034-2044.

A nested case control study from Spain, aimed to evaluate the association between use of different oral antidiabetic agents (OAD) and the risk of community-acquired pneumonia (CAP) in patients with type-2 diabetes (T2DM).

73.Richter B, Bandeira-Echtler E, Bergerhoff K, Lerch CL. Dipeptidyl peptidase-4 (DPP-4) inhibitors for type 2 diabetes mellitus. Cochrane Database Syst Rev. 2008 Apr 16; (2) : CD006739.

74. Gooßen K, Gräber S. Longer term safety of dipeptidyl peptidase-4 inhibitors in patients with type 2 diabetes mellitus: systematic review and metaanalysis. Diabetes Obes Metab. 2012; 14(12):1061-72.

75. Singh S, Loke YK, Furberg CD. Long-term use of thiazolidinediones and the associated risk of pneumonia or lower respiratory tract infection: systematic review and meta-analysis. Thorax. 2011 May;66(5):383-8. 


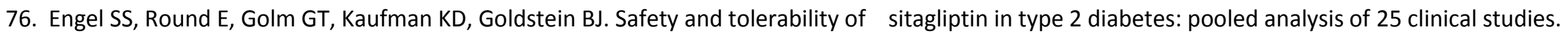
Diabetes Ther. 2013; 4(1):119-45.

77.Lydia Finney, Matthew Berry, Aran Singanayagam, et al. Inhaled corticosteroids and pneumonia in chronic obstructive pulmonary disease. LancetRespirMed 2014 Nov; 2(11): 919-932.

78.European Medicines Agency (2016) Review by the Committee for Medicinal Products for Human Use: Inhaled corticosteroids containing medicinal products indicated in the treatment of chronic obstructive pulmonary disease. Published 18th March 2016. Accessed May 2016.

79.http://goldcopd.org/gold-2017-global-strategy-diagnosis-management-prevention-copd/

80.Magnussen H, Disse B, Rodriguez-Roisin R, et al. Withdrawal of inhaled glucocorticoids and exacerbations of COPD. N Engl J Med 2014; 371(14): 1285-94.

A 12-month study demonstrated that in patients with severe COPD receiving tiotropium plus salmeterol, the risk of moderate or severe exacerbations was similar among those who discontinued inhaled glucocorticoids and those who continued glucocorticoid therapy.

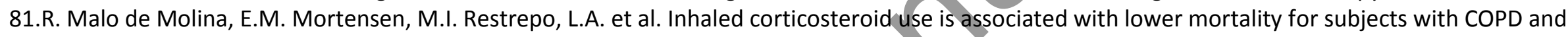
hospitalized with pneumonia. Eur Respir J 2010; 36: 751-757.

82.Dransfield MT, Feldman G, Korenblat P, et al. Efficacy and safety of once-daily fluticasone furoate/vilanterol (100/25 mcg) versus twice-daily fluticasone propionate/salmeterol (250/50 mcg) in COPD patients. RespirMed. 2014 Aug; 108(8): 1171-9.

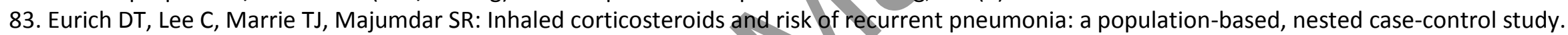
Clin Infect Dis 2013; 57: 1138- 1144.

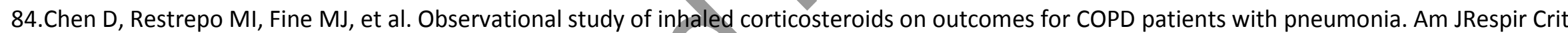
Care Med 2011; $184: 312-16$.

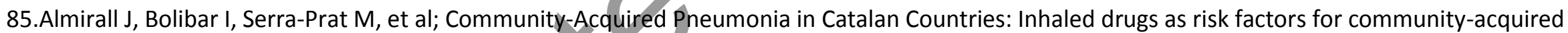
pneumonia. Eur Respir J 2010; 36: 1080-1087.

86. Trifirò G. Antipsychotic drug use and community-acquired pneumonia. Curr Infect Dis Resp 2011; 13: 262-268.

A review aiming to revise and discuss the scientific evidence and biologic explanations for the association between atypical and typical antipsychotic use and pneumonia occurrence.

87. Nosè M, Recla E, Trifirò G, Barbui C. Antipsychotic drug exposure and risk of pneumonia: a systematic review and meta-analysis of observational studies. Pharmacoepidemiol Drug Saf. 2015 Aug; v 24(8): 812-20.

88.Sultana J, Calabró M, Garcia-Serna R, et al. Biological substantiation of antipsychotic-associated pneumonia: Systematic literature review and computational analyses. PLoS One. 2017 Oct 27;12(10):e0187034.

A literature review investigating the known mechanisms of AP-associated pneumonia

, confirm these mechanisms using an independent data source on drug targets and attempt to identify novel AP drug targets potentially linked to pneumonia.

89. Sultana J, Fontana A, Giorgianni F, et al. Can information on functional and cognitive status improve short-term mortality risk prediction among community-dwelling older people? A cohort study using a UK primary care database. Clin Epidemiol. 2017 Dec 19; 10 :31-39. 
90.Chey WD, Mody RR, Wu EQ, et al. Treatment patterns and symptom control in patients with GERD: US community-based survey. Current medical research and opinion. 2009; 25(8): 1869-78.

91.De Jager C, Wever P, Gemen E, et al. Proton pump inhibitor therapy predisposes to community-acquired Streptococcus pneumoniae pneumonia. Aliment Pharmacol Ther 2012; 36: 941-949.

92.S.C.A. Meijvis, M.C.A. Cornips, G.P. Voorn, et al. Microbial evaluation of proton-pump inhibitors and the risk of pneumonia. Eur Respir J 2011; 38: $1165-1172$.

93.Yoshida N, Yoshikawa T, Tanaka Y, et al. A new mechanism for anti-inflammatory actions of proton pump inhibitors-inhibitory effects on neutrophilendothelial cell interactions. Aliment Pharmacol Ther 2000; 14: Suppl. 1, 74-81. 
Table 1. Studies examining the risk for CAP in COPD patients treated with ICSs

\begin{tabular}{|c|c|c|c|c|c|c|c|c|}
\hline Authors & Study Period & Design & Setting & Population & & Exposure & $\begin{array}{l}\text { Main } \\
\text { Findings: } \\
\text { RR or } \\
\text { Incidence }\end{array}$ & $\begin{array}{l}\text { Dose } \\
\text { effect }\end{array}$ \\
\hline $\begin{array}{l}\begin{array}{l}\text { Calverley P et } \\
\text { al }^{14}\end{array} \\
\text { TORCH Trial }\end{array}$ & $2000-2006$ & RCT & $\begin{array}{l}\text { Outpatients } \\
44 \text { centers in } \\
42 \text { countries }\end{array}$ & $\begin{array}{l}\text { Patients } 40-80 \text { years old with } \\
\text { moderate-severe } \\
\operatorname{COPD}(\mathrm{N}=6,112)\end{array}$ & Mortality & $\begin{array}{l}\text { FC }(1,000 \mu \mathrm{g}) \\
\operatorname{SFC}(1,000 \\
\mu \mathrm{g})\end{array}$ & $\begin{array}{l}1.52(95 \% \\
\mathrm{Cl}: 1.32- \\
1.76)\end{array}$ & NA \\
\hline $\begin{array}{l}\text { Anzueto A et } \\
\text { al }^{17}\end{array}$ & $\begin{array}{l}2007-2008 \\
1 \text { year }\end{array}$ & RCT & Outpatients & $\begin{array}{l}\text { Moderate to severe } \\
\mathrm{COPD}(\mathrm{N}=782)\end{array}$ & $\begin{array}{l}\text { Overall } \\
\text { mortality } \\
\text { Pneumonia }\end{array}$ & $\mathrm{FC}(500 \mu \mathrm{g})$ & $\begin{array}{l}7 \% \text { vs. } 2 \% \\
\text { (LABA) }\end{array}$ & NA \\
\hline $\begin{array}{l}\text { Kardos } P \text {, et } \\
\text { al }^{18}\end{array}$ & $\begin{array}{l}\text { 2002-2003 } \\
44 \text { weeks }\end{array}$ & RCT & Outpatients & $\begin{array}{l}\text { Severe COPD pts with history } \\
\text { of exacerbations } \\
(n=994)\end{array}$ & $\begin{array}{l}\text { COPD } \\
\text { exacerbations } \\
\text { Pneumonia } \\
\text { side effect }\end{array}$ & SFC $(1000 \mu \mathrm{g})$ & $\begin{array}{l}4.6 \% \text { vs. } \\
1.43 \% \\
\text { LABA) }\end{array}$ & NA \\
\hline $\begin{array}{l}\text { Sharafkhaneh } \\
\text { A et } \mathrm{al}^{22} \text {. }\end{array}$ & $\begin{array}{l}2007-2009 \\
(1 \text { year) }\end{array}$ & & Outpatients & $\begin{array}{l}\text { patients }>40 \text { years with COPD } \\
\text { moderate to severe, with } \\
\text { anexacerbation/year }(\mathrm{N}=1,219)\end{array}$ & $\begin{array}{l}\text { Pneumonia } \\
\text { \& Mortality }\end{array}$ & $\begin{array}{l}\text { FBD }(320 \mu \mathrm{g} \\
\text { and } 160 \mu \mathrm{g})\end{array}$ & $\begin{array}{l}6.4 \% \text { (320 } \\
\mu g) v s . \\
4.7 \%(160 \\
\mu g) v s . \\
2.7 \% \\
\text { (LABA) }\end{array}$ & NS \\
\hline
\end{tabular}




\begin{tabular}{|c|c|c|c|c|c|c|c|c|}
\hline $\begin{array}{l}\text { Dransfield M } \\
\text { et al. }{ }^{82}\end{array}$ & $\begin{array}{l}\text { 2011-2012 } \\
\text { (12 weeks) }\end{array}$ & RCT & Outpatients & $\begin{array}{l}\text { Patients }>40 \text { years, moderate } \\
\text { to severe } \operatorname{COPD}(\mathrm{N}=1860)\end{array}$ & $\begin{array}{l}\text { Pneumonia } \\
\text { Pneumonia } \\
\text { Mortality }\end{array}$ & $\begin{array}{l}\operatorname{VFFg}(50 \mu \mathrm{g}, \\
100 \mu \mathrm{g}, \text { and } \\
200 \mu \mathrm{g})\end{array}$ & $\begin{array}{l}7.3 \% \text { vs. } \\
3.4 \% \\
\text { (LABA) }\end{array}$ & NS \\
\hline $\begin{array}{l}\text { Wedzicha J et } \\
\text { al }^{15} \text {. }\end{array}$ & $\begin{array}{l}2003-2004 \\
2 \text { years }\end{array}$ & $\mathrm{RCT}$ & Outpatients & $\begin{array}{l}\text { Patients }>40 \text { years, severe - } \\
\text { very severe COPD }(N=1,323)\end{array}$ & Pneumonia & $\begin{array}{l}\text { SFC }(500 \mu \mathrm{g}) \\
\text { LAMA }(18 \mu \mathrm{g})\end{array}$ & $\begin{array}{l}1.94(95 \% \\
\mathrm{Cl}: 1.19- \\
3.17)\end{array}$ & NA \\
\hline $\begin{array}{l}\text { Crim C et al }{ }^{34} \text {. } \\
\text { (SUMMIT Trial) }\end{array}$ & $\begin{array}{l}2011-2014 \\
3 \text { years }\end{array}$ & RCT & Outpatients & $\begin{array}{l}\text { subjects }>40 \text { years with } \\
\text { moderate airflow limitation } \\
\text { and heightened cardiovascular } \\
\text { risk }(\mathrm{N}=16,568)\end{array}$ & $\begin{array}{l}\text { Pneumonia } \\
\text { Pneumonia } \\
\text { mortality }\end{array}$ & $\begin{array}{l}\text { VF }(25 \mu \mathrm{g} / 100 \\
\mu \mathrm{g}), \mathrm{VI}, \mathrm{FF}\end{array}$ & $\begin{array}{l}\text { Not } \\
\text { associated }\end{array}$ & No \\
\hline $\begin{array}{l}\text { Volgemeier C, } \\
\text { et al }{ }^{19} \\
\text { ILLLUMINATE } \\
\text { study }\end{array}$ & $\begin{array}{l}2011-2012 \\
26 \text { weeks }\end{array}$ & RCT & $\begin{array}{l}\text { Outpatients } \\
93 \text { centres in }\end{array}$ & $\begin{array}{l}\text { Patients age }>40 \text { years, GOLD } \\
\text { stages II-III, without } \\
\text { exacerbations in the previous } \\
\text { year }(\mathrm{N}=523)\end{array}$ & $\begin{array}{l}\text { Pneumonia } \\
\text { mortality }\end{array}$ & $\begin{array}{l}\text { QVA149 } \\
110 / 50 \mu g \\
\text { once daily } \\
\text { SFC 50/500 } \\
\mu g \text { twice daily }\end{array}$ & 0 vs. $1.5 \%$ & NS \\
\hline Ernst $P$ et al. ${ }^{28}$ & $\begin{array}{l}1998-2003 \\
14 \text { years }\end{array}$ & & Inpatient & $\begin{array}{l}\text { COPD } \\
\text { patients }>65 \text { years }(N=40366 \text {, } \\
n=79344)\end{array}$ & $\begin{array}{l}\text { Pneumonia } \\
\text { (Crude \& } \\
\text { Adjusted) }\end{array}$ & All ICS & $\begin{array}{l}1.70(95 \% \\
\mathrm{Cl}: 1.63- \\
1.77)\end{array}$ & Yes \\
\hline
\end{tabular}




\begin{tabular}{|c|c|c|c|c|c|c|c|c|}
\hline Suissa $S$ et al. ${ }^{21}$ & $\begin{array}{l}\text { 1990-2005 } \\
\text { Through } \\
2007\end{array}$ & Case-control & $\begin{array}{l}\text { Quebec health } \\
\text { insurance } \\
\text { databases }\end{array}$ & $\begin{array}{l}\text { COPD patients, ICS users } \\
(\mathrm{N}=163,514)\end{array}$ & $\begin{array}{l}\text { Serious } \\
\text { pneumonia } \\
\text { event, }\end{array}$ & FC, BUD & $\begin{array}{l}1.69(95 \% \\
\mathrm{Cl}: 1.63- \\
1.75)\end{array}$ & Yes \\
\hline Joo MJet al ${ }^{30}$ & $\begin{array}{l}1998-2002 \\
4 \text { years }\end{array}$ & Case-control & $\begin{array}{l}\text { Veterans } \\
\text { Affairs and } \\
\text { Centers for } \\
\text { Medicare and } \\
\text { Medicaid } \\
\text { Services } \\
\text { Database }\end{array}$ & $\begin{array}{l}\text { Patients }>65 \text { years with a new } \\
\text { diagnosis of COPD ( } N=145586 \text {; } \\
\text { cases=13995) }\end{array}$ & $\begin{array}{l}\text { Pneumonia } \\
\text { Mortality }\end{array}$ & All ICS & $\begin{array}{l}1.38(95 \% \\
\mathrm{Cl}: 1.31- \\
1.45)\end{array}$ & No \\
\hline $\begin{array}{l}\text { Mullerova } \mathrm{H} \text { et } \\
\mathrm{al}^{7}\end{array}$ & $1996-2005$ & $\begin{array}{l}\text { Retrospective } \\
\text { cohort }\end{array}$ & $\begin{array}{l}\text { General } \\
\text { Research } \\
\text { Practice } \\
\text { Database } \\
\text { (GPRD) }\end{array}$ & $\begin{array}{l}\text { A cohort of COPD patients } \\
\text { aged }>45 \text { years }\end{array}$ & $\begin{array}{l}\text { Risk factors } \\
\text { for CAP in } \\
\text { COPD patients }\end{array}$ & All ICS & $\begin{array}{l}\text { Not } \\
\text { associated }\end{array}$ & NA \\
\hline $\begin{array}{l}\text { Janson C et } \\
\text { al. }^{29}\end{array}$ & $1999-2009$ & $\begin{array}{l}\text { Retrospective } \\
\text { cohort }\end{array}$ & $\begin{array}{l}\text { Swedish } \\
\text { National } \\
\text { Board of } \\
\text { Health and }\end{array}$ & $\begin{array}{l}\text { COPD patients } \\
(\mathrm{N}=9,893)\end{array}$ & $\begin{array}{l}\text { Pneumonia, } \\
\text { mortality }\end{array}$ & FBD, SFC & $\begin{array}{l}1.73(95 \% \\
\mathrm{Cl}: 1.57- \\
1.90) \text { vs. } \\
1.74 \\
(1.56- \\
1.94)\end{array}$ & NA \\
\hline Mapel D $D^{33}$ & $2000-2003$ & $\begin{array}{l}\text { Nested case- } \\
\text { control }\end{array}$ & $\begin{array}{l}\text { Databases of } \\
\text { three large } \\
\text { regional } \\
\text { managed care } \\
\text { organizations }\end{array}$ & COPD patients $(\mathrm{N}=5,245)$ & Pneumonia & All ICS & $\begin{array}{l}1.29(95 \% \\
\mathrm{Cl}: 0.96- \\
1.73)\end{array}$ & NA \\
\hline
\end{tabular}




\begin{tabular}{|c|c|c|c|c|c|c|c|c|}
\hline Gau JT et al. ${ }^{10}$ & $2004-2006$ & Case-control & $\begin{array}{l}\text { A rural } \\
\text { community } \\
\text { hospital }\end{array}$ & $\begin{array}{l}\text { adults aged }>65 \text { years } \\
(\mathrm{N}=194 \\
\text { Controls: } 952)\end{array}$ & $\begin{array}{l}\text { Pneumonia } \\
\text { event }\end{array}$ & $\begin{array}{l}\text { All ICS, } \\
\text { atypical } \\
\text { antipsychotics } \\
\text { and PPIs }\end{array}$ & $\begin{array}{l}2.89(95 \% \\
\mathrm{Cl}: 1.56- \\
5.35)\end{array}$ & NA \\
\hline Festic $\mathrm{E}$ et $\mathrm{al}^{36}$ & $\begin{array}{l}2009 \\
2 \text { years }\end{array}$ & $\begin{array}{l}\text { prospective } \\
\text { cohort }\end{array}$ & $\begin{array}{l}\text { LIPS cohort } \\
\mathrm{N}=5884\end{array}$ & $\begin{array}{l}\text { COPD patients taking ICS } \\
\mathrm{N}=589\end{array}$ & $\begin{array}{l}\text { Pneumonia } \\
\text { hospitalization }\end{array}$ & All ICS & $\begin{array}{l}1.40(95 \% \\
\mathrm{Cl} 0.95- \\
2.09 ; \\
\mathrm{p}=0.093)\end{array}$ & NA \\
\hline $\begin{array}{l}\text { DiSantostefano } \\
\text { R et al. }{ }^{32}\end{array}$ & $2002-2010$ & $\begin{array}{l}\text { Observational } \\
\text { cohort }\end{array}$ & $\begin{array}{l}\text { United } \\
\text { Kingdom } \\
\text { electronic } \\
\text { medical } \\
\text { records with } \\
\text { linked } \\
\text { hospitalization }\end{array}$ & $\begin{array}{l}\text { Pneumonia events in COP } \\
\text { patients }>45 \\
\text { years were compared am } \\
\text { new users of ICS } \\
(\mathrm{N}=11,555)\end{array}$ & $\begin{array}{l}\text { Risk of } \\
\text { pneumonia }\end{array}$ & All ICS & $\begin{array}{l}1.49(95 \% \\
\mathrm{Cl}: 1.22- \\
1.83)\end{array}$ & Yes \\
\hline
\end{tabular}

ICS, inhaled corticosteroids; COPD, chronic obstructive pulmonary disease; RR, relative risk; FC, fluticasone propionate; SFC, salmeterol plus fluticasone; 
Table 2. Studies investigating PPIs as risk factors for pneumonia.

\begin{tabular}{|c|c|c|c|c|c|c|c|}
\hline Authors & $\begin{array}{l}\text { Study } \\
\text { period }\end{array}$ & Design & Setting & Population & Outcome & $\begin{array}{l}\text { Exposur } \\
\mathrm{e}\end{array}$ & $\begin{array}{l}\text { Main Findings } \\
\text { Adj OR }\end{array}$ \\
\hline $\begin{array}{l}\text { Sugano et } \\
\text { al }^{39}\end{array}$ & $2007-2009$ & RCT & \begin{tabular}{|l|}
47 \\
healthcare \\
institutions
\end{tabular} & $\begin{array}{l}\text { Long-term NSAID } \\
\text { users with history } \\
\text { of }\end{array}$ & Pneumonia & PPIs & Not associated \\
\hline $\begin{array}{l}\text { Laheij RJ et } \\
\text { al. }^{40}\end{array}$ & $1995-2002$ & $\begin{array}{l}\text { Nested case- } \\
\text { control }\end{array}$ & $\begin{array}{l}\text { Integrated } \\
\text { Primary Care } \\
\text { Information } \\
\text { database }\end{array}$ & $\begin{array}{l}\text { incident users of } \\
\text { IPPS ( } N=364683 \text {, } \\
n=5551)\end{array}$ & Pneumonia & PPIs & Current use: 1.73 (1.33-2.25) \\
\hline $\begin{array}{l}\text { Gulmez SE et } \\
\text { al. }^{41}\end{array}$ & $2000-2004$ & $\begin{array}{l}\text { Population } \\
\text { based case- } \\
\text { control }\end{array}$ & $\begin{array}{l}\text { Government } \\
\text { Patient } \\
\text { Registries } \\
\text { County of } \\
\text { Funen, } \\
\text { Denmark }\end{array}$ & $\begin{array}{l}\text { Patients with } \\
\text { pneumonia; } \\
\mathrm{N}=7642 \\
\text { Controls=34 } 176\end{array}$ & Pneumonia & PPIs & $\begin{array}{l}\text { Current use: } 1.5 \text { (1.3-1.7) } \\
\text { Past use: } 1.2 \text { (0.9-1.6) } \\
\text { Initiation: } 5 \text { (2.1-11.7) }\end{array}$ \\
\hline
\end{tabular}




\begin{tabular}{|c|c|c|c|c|c|c|c|}
\hline $\begin{array}{l}\text { Sarkar M et } \\
\text { al. } .^{44}\end{array}$ & $1987-2002$ & $\begin{array}{l}\text { Nested case- } \\
\text { control }\end{array}$ & $\begin{array}{l}\text { The General } \\
\text { Practice } \\
\text { Research } \\
\text { Database in } \\
\text { the UK }\end{array}$ & $\begin{array}{l}\text { Patients }>18 \\
\text { years old, } 6 \\
\text { months after } \\
\text { pneumonia. PPIs } \\
\text { users within } 30 \\
\text { days before the } \\
\text { index date } \\
\text { Cases }=80,066, \\
\text { controls }=779881\end{array}$ & Pneumonia & PPIs & $\begin{array}{l}\text { Initiation 2D: } 6.53(3.95-10.80) \text {, } \\
\text { 7D: } 3.79(2.66-5.42) \text {, } \\
\text { 14D: } 3.21(2.46-4.18)\end{array}$ \\
\hline $\begin{array}{l}\text { Rodriguez LA } \\
\text { et al. }{ }^{43}\end{array}$ & $2000-2005$ & Case control & $\begin{array}{l}\text { Health } \\
\text { Improvemen } \\
\text { t Network } \\
\text { database }\end{array}$ & $\begin{array}{l}\text { Patients aged } 20- \\
79 \text { years with a } \\
\text { new diagnosis of } \\
\text { pneumonia }\end{array}$ & $\begin{array}{l}\text { Risk of } \\
\text { pneumonia }\end{array}$ & $\begin{array}{l}\text { PPIs } \\
\mathrm{H}_{2} \mathrm{RAs}\end{array}$ & $\begin{array}{l}\text { RR: } \\
\text { PPIs:1.16 (1.03-1.3), } \\
\mathrm{H}_{2} \text { RAs:0,98(0,8-1,2) }\end{array}$ \\
\hline $\begin{array}{l}\text { Myles PR et } \\
\text { al. }{ }^{42}\end{array}$ & $2001-2002$ & $\begin{array}{l}\text { Population- } \\
\text { based case- } \\
\text { control }\end{array}$ & $\begin{array}{l}\text { Health } \\
\text { improvemen } \\
\text { t Network } \\
\text { (THIN) }\end{array}$ & $\begin{array}{l}\text { Patients }>40 \\
\text { years } \\
\text { Old- inpatients or } \\
\text { outpatients } \\
\mathrm{N}=3,709\end{array}$ & Pneumonia & $\begin{array}{l}\text { statins, } \\
\text { ACE } \\
\text { inhibitor } \\
\text { s (ACEI), } \\
\text { PPIs, H2 } \\
\text { RAs }\end{array}$ & $\begin{array}{l}\text { PPIs:1.55 (1.35-1.77) } \\
\text { H }_{2} \text { RAs:1.14,( 0.92-1.40) }\end{array}$ \\
\hline $\begin{array}{l}\text { Meijvis SCA et } \\
\text { al }^{90} \text {. }\end{array}$ & $2004-2010$ & $\begin{array}{l}\text { Population- } \\
\text { based Case- } \\
\text { control }\end{array}$ & $\begin{array}{l}\text { PHARMO } \\
\text { Record } \\
\text { Linkage } \\
\text { System } \\
\text { Database } \\
\text { and } 2\end{array}$ & $\begin{array}{l}\text { Patients with CAP } \\
\text { admitted to } \\
\text { hospital } \\
\text { cases }=430 \\
\text { Controls=2,150 }\end{array}$ & Pneumonia & PPIs & Current use: 3,1 (1.4-7.1) \\
\hline
\end{tabular}




\begin{tabular}{|c|c|c|c|c|c|c|c|}
\hline & & & $\begin{array}{l}\text { hospitals in } \\
\text { Netherland }\end{array}$ & & & & \\
\hline $\begin{array}{l}\text { De Jager Ce } \\
\mathrm{t} \text { al }\left.\right|^{89} \text {. }\end{array}$ & $2007-2010$ & $\begin{array}{l}\text { Prospective } \\
\text { cohort }\end{array}$ & Outpatients & $\begin{array}{l}\text { Patients having } \\
\text { CAP seen on the } \\
\text { emergency care } \\
\text { unit }(N=463)\end{array}$ & $\begin{array}{l}\text { CAP from } \\
\text { Str.pneum } \\
\text { oniae \& } \\
\text { CAP } \\
\text { severity }\end{array}$ & PPIS & $2(1.22-3.72)$ \\
\hline Ho SW et al ${ }^{45}$ & $2009-2013$ & $\begin{array}{l}\text { Retrospectiv } \\
\text { e population- } \\
\text { based cohort }\end{array}$ & $\begin{array}{l}\text { Taiwanese } \\
\text { National } \\
\text { Health } \\
\text { Insurance } \\
\text { Research } \\
\text { Database }\end{array}$ & $\begin{array}{l}\text { Adult patients } \\
\text { aged } \geq 40 \text { years } \\
\text { with new-onset } \\
\text { dementia } \\
\text { Cases:786 }\end{array}$ & & PPls & $\mathrm{HR}=1.89 ; 1.51-2.37)$ \\
\hline
\end{tabular}

H2RAs = histamine2-receptor antagonists, PPIs:Proton Pumb Inhibitors; $\mathrm{Cl}=$ confidence interval, CAP: community acquired pneumonia 


\section{Table 3. Observational studies investigating the risk for pneumonia associated with antipsychotic medication}

\begin{tabular}{|c|c|c|c|c|c|c|}
\hline Authors & Study design & Setting & Population & Outcome & Exposure & Main findings \\
\hline Knol $W$ et al. ${ }^{58}$ & $\begin{array}{l}\text { Nested case- } \\
\text { control }\end{array}$ & $\begin{array}{l}\text { Dutch } \\
\text { PHARMO } \\
\text { database }\end{array}$ & $\begin{array}{l}\text { Patients }>65 \text { years } \\
\text { newly treated with } \\
\text { Aps }(N=22,944 ; n= \\
543 \text { cases })\end{array}$ & $\begin{array}{l}\text { Hospital } \\
\text { admission } \\
\text { due to } \\
\text { pneumonia }\end{array}$ & $\begin{array}{l}\text { AAPs orTAPs } \\
\text { (non-use as } \\
\text { comparator) }\end{array}$ & $\begin{array}{l}\text { Adj OR: Current use of } \\
\text { AAPs: } 3.10(1.89-5.07) \\
\text { TAPs: } 1.5(1.2-1.9)\end{array}$ \\
\hline Barnett MJ ${ }^{56}$ & $\begin{array}{l}\text { Retrospective } \\
\text { cohort }\end{array}$ & $\begin{array}{l}\text { US Veterans } \\
\text { Administration } \\
\text { database }\end{array}$ & Hos & $\begin{array}{l}\text { In-hospital } \\
\text { mortality }\end{array}$ & $\begin{array}{l}\text { AAPs or TAPs } \\
\text { (no use Of } \\
\text { neuropsychia } \\
\text { tric drugs as } \\
\text { comparator) }\end{array}$ & $\begin{array}{l}\text { Adj OR:TAPs: } 1.5 \text { (1.0-2.2) } \\
\text { AAPs: } 1.2(1.0-1.5)\end{array}$ \\
\hline Trifiro G et al ${ }^{57}$ & $\begin{array}{l}\text { Nested case- } \\
\text { control }\end{array}$ & $\begin{array}{l}\text { Dutch general } \\
\text { practice } \\
\text { database } \\
\text { (Integrated } \\
\text { Primary Care } \\
\text { Information) }\end{array}$ & $\begin{array}{l}\text { Patients }>65 \text { years } \\
\text { newly treated with } \\
\text { APs }(N=258)\end{array}$ & $\begin{array}{l}\text { Fatal and } \\
\text { non-fatal } \\
\text { CAP }\end{array}$ & $\begin{array}{l}\text { AAPs or TAPs } \\
\text { (past use } \\
\text { of any AP as } \\
\text { comparator ) }\end{array}$ & $\begin{array}{l}\text { Adj. OR: fatal/non-fatal } \\
\text { pneumonia: } \\
\text { AAPs: } 2.61 \text { (1.48-4.61) } \\
\text { TAPs: } 1.76 \text { (1.22-2.53) } \\
\text { Fatal pneumonia: } \\
\text { AAPs: } 6.0(1.5-24.0) \\
\text { TAPs: } 1.7(0.8-3.9)\end{array}$ \\
\hline Gau GT et $\mathrm{al}^{10}$. & Case-control & $\begin{array}{l}\text { Rural } \\
\text { community }\end{array}$ & $\begin{array}{l}\text { USA, patients }>65 \\
\text { years }(N=194)\end{array}$ & CAP & $\begin{array}{l}\text { AAPs (non- } \\
\text { use as } \\
\text { comparator) }\end{array}$ & $\begin{array}{l}\text { Adj.OR: } \\
\text { AAPs:2.26 (1.23-4.15) }\end{array}$ \\
\hline
\end{tabular}




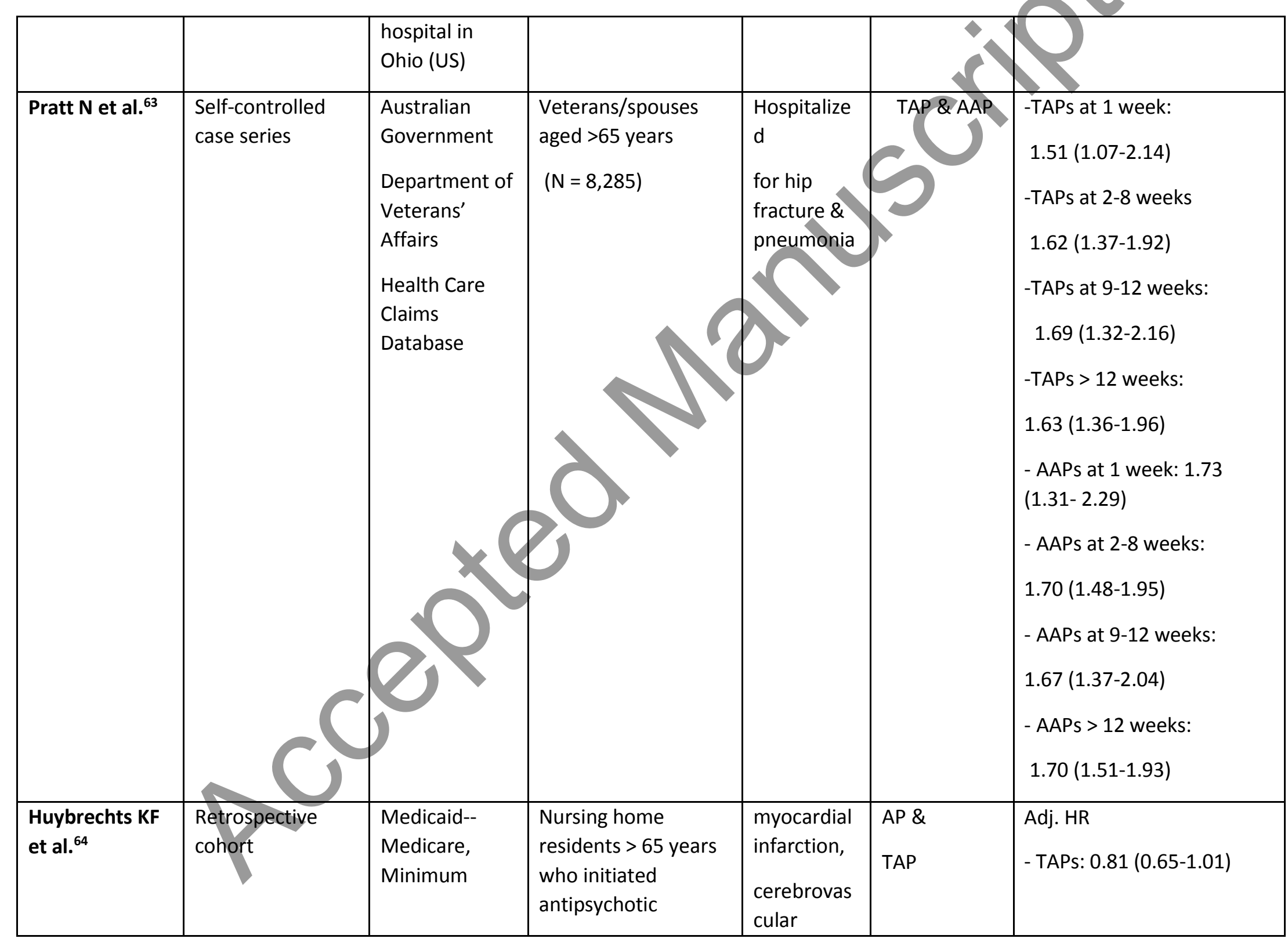




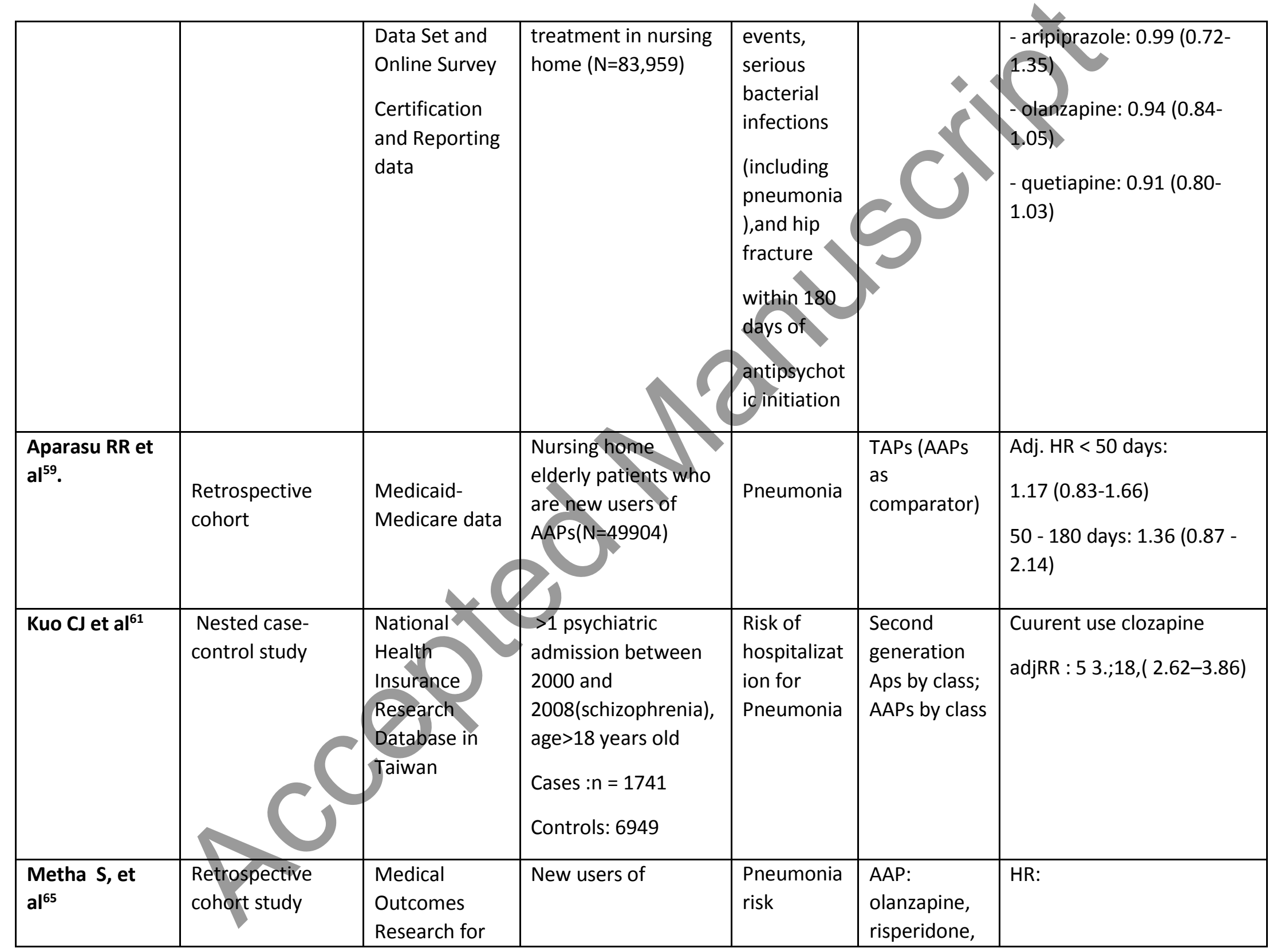




\begin{tabular}{|c|c|c|c|c|c|}
\hline & & $\begin{array}{l}\text { Effectiveness } \\
\text { and } \\
\text { Economics } \\
\text { Registry } \\
\text { (MORE2 } \\
\text { Registry) }\end{array}$ & $\begin{array}{l}\text { atypical } \\
\text { antipsychotics ( } \geq 65 \\
\text { years) } \\
(\mathrm{N}=92234 \text { ) }\end{array}$ & $\begin{array}{l}\text { quetiapine, } \\
\text { ziprasidone, } \\
\text { or } \\
\text { aripiprazole }\end{array}$ & $\begin{array}{l}\text { risperidone :1.14, (I 1.10- } \\
1.18 \text { ) and olanzapine : 1.10, } \\
(1.04-1.16) \text { compared with } \\
\text { the use of quetiapine. }\end{array}$ \\
\hline
\end{tabular}

\section{Risk estimates}

Adj, adjusted; AAPs, atypical antipsychotics; APs, antipsychotics; TAPs, typical antipsychotics; CAP: community acquired pneumonia;

$\mathrm{HR}$, hazard ratio; IRR, incidence rate ratio; $\mathrm{OR}$, odds ratio; $\mathrm{RR}$, rate ratio.

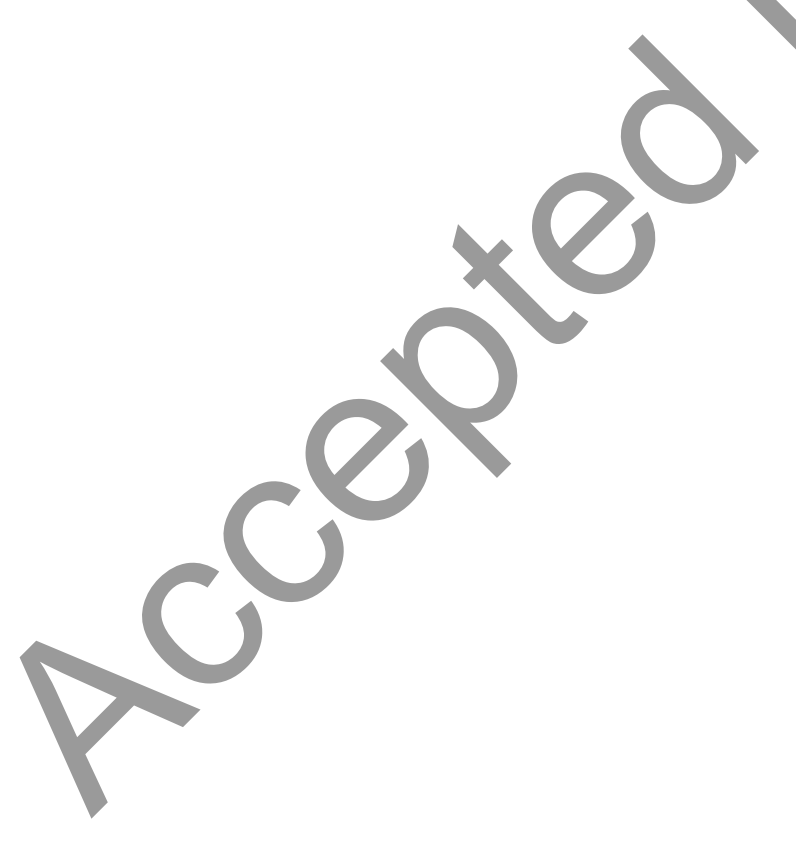


Table 4. Studies investigating the risk for pneumonia associated with oral antidiabetics

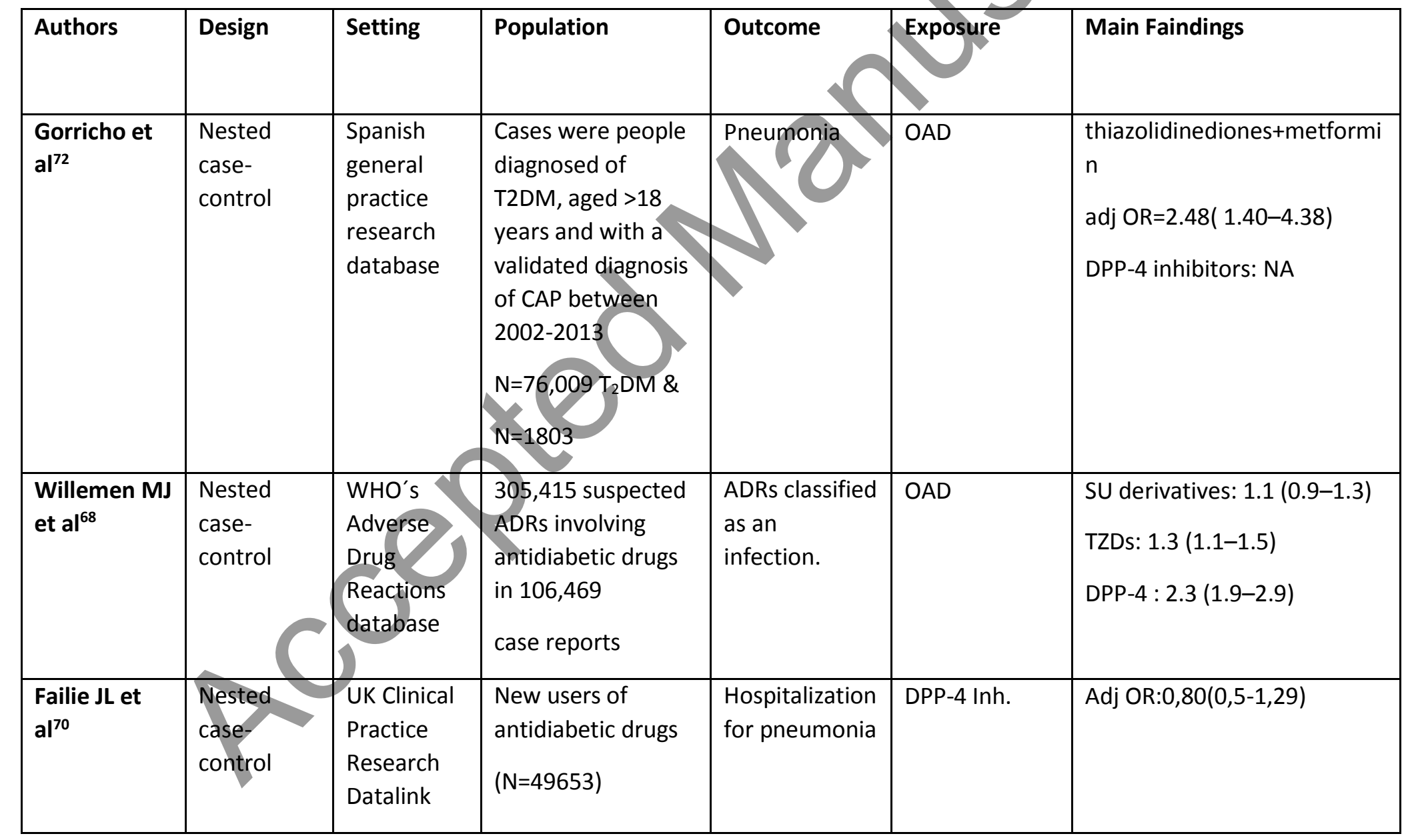




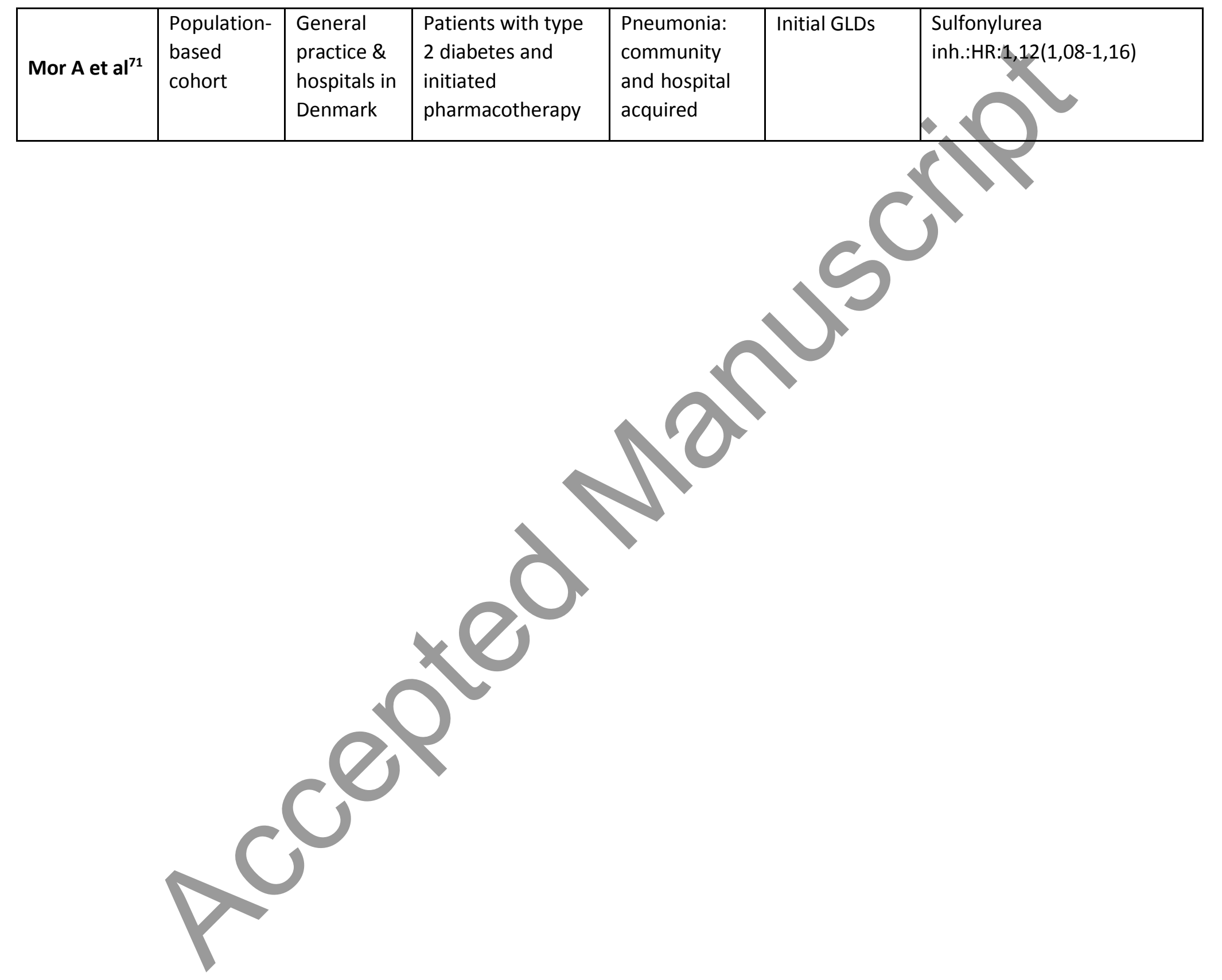




\begin{tabular}{|c|c|c|c|c|c|c|}
\hline $\begin{array}{l}\text { Wvan } \\
\text { der } \\
\text { Zanden } \\
R \text {, et }\end{array}$ & $\begin{array}{l}\text { Population- } \\
\text { Based } \\
\text { Cohort }\end{array}$ & CPRD & $\begin{array}{l}>18 \text { years } \\
\text { with DM } \\
\text { receiving } \\
\text { NIAD } \\
211,049 \text { NIAD }\end{array}$ & Pneumonia & NIAD & $\begin{array}{l}\text { current use of DPP4Is: } \\
\text { NA }\end{array}$ \\
\hline
\end{tabular}

OAD: oral antidiabetic drugs, GLDs: glucose lowering drugs, ADR: adverse drug reaction,

DPP-4 I: dipeptidyl peptidase inhibitors; SU: sulfonylurea; TZD: thiazolidinediones 